NBER WORKING PAPER SERIES

\title{
POLITICS IN THE COURTROOM: POLITICAL IDEOLOGY AND JURY DECISION MAKING
}

\author{
Shamena Anwar \\ Patrick Bayer \\ Randi Hjalmarsson \\ Working Paper 21145 \\ http://www.nber.org/papers/w21145
}

\author{
NATIONAL BUREAU OF ECONOMIC RESEARCH \\ 1050 Massachusetts Avenue \\ Cambridge, MA 02138 \\ May 2015
}

This research would not have been possible without the assistance of a number of individuals at the Gothenburg District Court. In particular, we would like to thank the two nämndemän coordinators, Assistant Judge Christoffer Önrup, Judge of Appeal Christer Ranch, and Assistant Judge David Caldevik for the their help answering numerous questions and Mikael Sjöberg in the Archives for his assistance collating all of the court documents. We would also like to thank two research assistants (Ulrika Kjellström and Magnus Landergren) for their help collecting the data and Matthew Lindquist, Emma von Essen, Erik Hjalmarsson, Johan Lönroth, and Jordi Blanes I Vidal as well as seminar participants at Queen Mary University of London, Gothenburg University, Aarhus, Leciester University, Stockholm School of Economics, Lund University, Växjö, the Swedish Institute for Social Research at Stockholm University, the Paris School of Economics and the Bath Crime Economics Workshop for valuable feedback. Hjalmarsson would also like to acknowledge funding from Vetenskapsrådet (The Swedish Research Council) and Jan Wallanders och Tom Hedelius Stiftelse Tore Browaldhs Stiftelse, P20140200:1. The views expressed herein are those of the authors and do not necessarily reflect the views of the $\mathbb{N}$ ational Bureau of Economic Research.

NBER working papers are circulated for discussion and comment purposes. They have not been peerreviewed or been subject to the review by the NBER Board of Directors that accompanies official NBER publications.

(C) 2015 by Shamena Anwar, Patrick Bayer, and Randi Hjalmarsson. All rights reserved. Short sections of text, not to exceed two paragraphs, may be quoted without explicit permission provided that full credit, including $\odot$ notice, is given to the source. 
Politics in the Courtroom: Political Ideology and Jury Decision Making

Shamena Anwar, Patrick Bayer, and Randi Hjalmarsson

NBER Working Paper No. 21145

May 2015

JEL No. K0,K14,K4

\begin{abstract}
This paper uses data from the Gothenburg District Court in Sweden and a research design that exploits the random assignment of politically appointed jurors (termed nämndemän) to make three contributions to the literature on jury decision-making: (i) an assessment of whether systematic biases exist in the Swedish nämndemän system, (ii) causal evidence on the impact of juror political party on verdicts, and (iii) an empirical examination of the role of peer effects in jury decision-making. The results reveal a number of systematic biases: convictions for young defendants and those with distinctly Arabic sounding names increase substantially when they are randomly assigned jurors from the far-right (nationalist) Swedish Democrat party, while convictions in cases with a female victim increase markedly when they are assigned jurors from the far-left (feminist) Vänster party. The results also indicate the presence of peer effects, with jurors from both the far-left and far-right parties drawing the votes of their more centrist peers towards their positions. Peer effects take the form of both sway effects, where jurors influence the opinions of their closest peers in a way that can impact trial outcomes, and dissent aversion, where jurors switch non-pivotal votes so that the decision is unanimous.
\end{abstract}

Shamena Anwar

Carnegie Mellon University

5000 Forbes Ave

Heinz College, Hamburg Hall Room 2116D

Pittsburgh, PA 15213

shamena@andrew.cmu.edu

Patrick Bayer

Department of Economics

Duke University

213 Social Sciences

Durham, NC 27708

and NBER

patrick.bayer@duke.edu
Randi Hjalmarsson

University of Gothenburg

Department of Economics

PO Box 640

40530 Gothenburg

Sweden

randi.hjalmarsson@economics.gu.se 


\section{Introduction}

The right of a defendant to a fair trial is an essential feature of any criminal justice system that respects the rule of law and, as such, is inscribed in the modern constitutions of the vast majority of nations. In countries with representative governments, criminal trials are typically decided by juries drawn from the local population in a manner intended to create representative participation in the legal system analogous to that in the political system, although the exact way juries are formed varies widely across countries. Many, particularly those that follow the English legal tradition, utilize juries of ordinary citizens selected randomly from the community, while others, including most of continental Europe, draw on a pool of lay judges or expert jurors selected through local elections or as political appointments (Jackson and Kovalev, 2006).

While the use of representative juries may provide a basis for popular legitimacy, the integrity of any criminal justice system ultimately depends on how close it comes to achieving the abstract promise of providing a fair trial for all defendants. A particular concern in many settings is whether juries exhibit systematic biases for or against certain defendants (or victims) in a way that impacts verdicts beyond the objective quality of the evidence in the case. While no system is likely to eliminate all such bias, much of the ongoing academic and legal debate surrounding alternative jury systems is focused on whether certain designs are more likely to minimize it (Hans, 2008).

Despite the fundamental importance of these questions for the fairness and integrity of criminal justice systems, there is surprisingly little hard evidence on jury decision-making using data from actual trials anywhere in the world. The lack of empirical research is due first and foremost to restrictions or severe limitations on the use of trial data, especially in countries outside of the United States. As a result, the current empirical literature consists 
primarily of a small number of correlation studies using data from the United States. ${ }^{1,2}$ Unfortunately, these studies are generally subject to concerns about the non-random selection of the seated jury, making it difficult to draw strong causal conclusions about the effects of jury composition on verdicts.

A recent pair of studies (Anwar, Bayer and Hjalmarsson; 2012, 2014) provides causal evidence of biases in U.S. jury decisions by exploiting random aspects of the assignment of juries to felony cases in two counties in Florida. Specifically, these studies take advantage of the random variation in the day-to-day composition of the jury pool from which the jury is chosen. These papers make clear that verdicts are not simply a function of the objective quality of the evidence in the case, showing instead that that trial outcomes vary systematically and significantly with random fluctuations in the composition of juries (including juror race and age). Importantly, this kind of causal evidence is limited so far to this single setting, raising concern about the external validity of the existing findings; analogous studies simply do not exist for other jurisdictions within the U.S. or for alternative jury systems in other countries. ${ }^{3}$ Because the vast majority of trials are conducted by local jurisdictions (e.g., municipalities, counties) in most countries, the broad validity of this kind

\footnotetext{
${ }^{1}$ See Diamond and Rose (2005) for a review of studies using data from jury trials. More recently, Lehmann and Smith (2013) look at the impact of a variety of seated juror characteristics (race, gender, age, religiousness, education, and income) on trial outcomes and Lee (2014) shows that states that switched from key-man jury selection procedures to more random selection procedures, which were meant to increase black representation on juries, saw a resulting drop in the share of non-whites newly admitted to prison.

${ }^{2}$ In the absence of data from real trials, researchers have also conducted mock trials, but the resulting conclusions are limited by both the simplifications made for experimental expediency and the substantially lower stakes compared to real criminal trials. See Devine et. al. (2001) for a survey of this literature.

${ }^{3}$ There is a more substantial literature on judges, both in the US and internationally, as opposed to juries. A number of papers look at random assignment of judges, including Abrams et. al (2012) who study racial differences in sentencing and Ashenfelter et. al (1995) who study the effect of judicial ideology in Federal courts. See, for instance, Shayo and Zussman (2011) and Gazal-Ayal and Sulitzeanu-Kenan (2010) for studies of judicial in-group bias in Israeli small claims courts and bail hearings, respectively. Casper and Zeisel (1972) conducted an early study of German lay judges.
} 
of research depends crucially on increasing the number of carefully designed jury studies using data from settings throughout the world. ${ }^{4}$

With this context in mind, this paper uses a novel data set of criminal cases tried in Gothenburg, Sweden to make three broad contributions to the empirical literature on jury decision-making. By way of background, serious criminal cases in Sweden are decided by a professional judge in collaboration with three lay jurors (termed nämndemän), who are drawn (essentially) randomly from a pool of eligible nämndemän in the district. Nämndemän are politically affiliated, appointed officials that serve on many trials during their four-year term.

The first main goal of our analysis is to assess whether nämndemän exhibit systematic biases based on the characteristics of the defendant or case. To do so, we take advantage of the random assignment of nämndemän triplets (juries) to cases, examining how conviction rates vary with the assignment of different types of nämndemän. This research design naturally avoids the primary concerns with correlation studies in settings where the jury is seated through a pre-trial selection process and allows us to test whether nämndemän systematically reach different verdicts when faced with statistically identical evidence.

Second, our analysis provides the first causal evidence on the role that political affiliations play in jury decision-making. Given the general perception that views on criminal justice issues are related to political and ideological leanings, it is surprising that political party does not appear in reviews of more than 100 jury studies (Devine et al, 2001; Devine, 2012). ${ }^{5}$ In contrast, political ideology has been considered more extensively in the context of judicial decision-making, where many judges are politically appointed or elected. ${ }^{6}$

\footnotetext{
${ }^{4}$ Put another way, external validity for research on jury decision making will only be possible in the long run through the aggregation of many carefully designed studies, each of which analyzes data drawn from a particular local context.

${ }^{5}$ The only reference we have come across is Tuerkheimer's (2008) discussion of a mock trial conducted by a litigation consulting firm (Zagnoli McEvoy Foley). The findings of this study suggest that political leanings are related to a perspective juror's views on civil damages, but not his actions in the courtroom.

${ }^{6}$ This literature considers a wide range of cases, including EPA (Revesz, 1997; Miles and Sunstein, 2006), NLRB (Miles and Sunstein, 2006), criminal appeals, death penalty, and abortion (Sunstein et. al. 2006). It generally finds that a judge's politics matter - Democratic judges are more favorable in liberal cases while
} 
The final component of our analysis uses the random assignment of nämndemän triplets to cases in a complementary way to explore the role of peers in jury decision making and, in so doing, begin to provide some empirical evidence on how jurors work together to reach decisions. In particular, the repeated randomized structure of nämndemän assignment provides interesting variation not only in the matching of nämndemän to defendants but also in the matching of nämndemän to each other. In this way, we observe the same individual serving with different sets of peers across a large number of different cases. This unique structure allows us to identify the causal impact of nämndemän on one another.

Because of legislation in the 1950 s prohibiting the observation and recording of deliberations in U.S. trials, how real juries arrive at verdicts largely remains a black box. Much of what is known about jury deliberations is based on mock trials ${ }^{7}$ there is almost no research on the dynamics of jury decision-making using data from actual trials. One recent exception is Hans and Waters (2009) analysis of juror surveys from The Hung Jury Project; more than half of the unanimous jury verdicts had at least one juror who would have voted differently than the actual verdict if voting independently. While this result is clearly suggestive that group dynamics matter, we are unaware of any studies that directly estimate the impact of peers on jury decision-making. ${ }^{8}$

Republican judges are more favorable in conservative cases (Spitzer and Talley, 2013). With respect to sentencing in criminal cases, Schanzenbach and Tiller (2008) find evidence of harsher sentences from Republican appointed judges. Iaryczower and Shum's (2012) study of the Supreme Court finds that while the justices' initial leanings are changed in more than 40 percent of cases after incorporating 'information', such changes have become less likely as appointments to the court has become more politicized. Finally, Lim, Snyder, and Strömberg (forthcoming) study how media coverage differentially affects sentence length for partisan and non-partisan judges; they find that it leads to harsher sentences for the latter but has no effect on the former.

${ }^{7}$ MacCoun's (1989) brief review of this literature highlights two phenomena: (i) a majority effect, whereby a verdict can be predicted fairly reliably by a two-thirds majority, even when there is a unanimous decision rule and (ii) group polarization, where deliberations make group members more extreme in their views than they were before deliberating.

${ }^{8}$ A related literature studies panel effects in U.S. circuit court judicial decision-making. Much of this literature documents the existence of judicial peer effects; see, for instance, Boyd et al (2010) for a study of judge gender. Fischman (2013) reanalyzes more than ten previous studies of judge panel effects, concluding that the estimated peer effects are consistent with a strong norm of consensus. Other papers test the potential mechanisms underlying these peer effects; see, for instance, Miles (2012). Amongst the main mechanisms put forth are whistleblowing (Cross and Tiller, 1998), dissent aversion (Epstein et al, 2011; Posner, 2008), and the dynamics 
The data used in this paper consist of more than 950 closed crimes against person cases for the Gothenburg District Court for 2009 to 2012, representing more than 1,150 defendant by case observations. For each case, documents were obtained from the Court Archives that provide the names of the judge and nämndemän, defendant and case characteristics, the outcome, and any dissenting opinions (as verdicts do not have to be unanimous in the Swedish judicial system). These data were merged with a secondary data set of nämndemän characteristics, including political party, gender, birth year, and years of experience.

There are nine political parties represented in the data. The two predominant parties, as in Swedish politics in general, are the Social Democrats and Moderates; in fact, there is at least one Social Democrat and one Moderate on 74 and 69 percent of cases, respectively. Thus, variation in the composition of the nämndemän triplets comes primarily from those parties that are more extreme in the political spectrum and, as a result, our empirical specifications focus on two parties on the far left (Vänster (left) and Green) and one on the far right (Swedish Democrats), who have the most soft- and hard-on-crime attitudes, respectively.

The first part of our empirical analysis uses this defendant by case level data to assess whether certain kinds of defendants and cases are more (or less) likely to be convicted when randomly assigned nämndemän from these most liberal and conservative parties, respectively. The results of the analysis reveal substantial systematic biases with respect to political affiliation in the Swedish system of lay judges. The presence of a Swedish Democrat in the triplet increases the likelihood of conviction by 17 percentage points for defendants with Arabic names, which is consistent with the Swedish Democrats' nationalist, anti-immigration platform. Having a Vänster in the triplet increases convictions by 14 percentage points when there is a female victim, consistent with the party's feminist platform. These results, which are robust to a variety of specifications, suggest that the impact of political party on 
conviction decisions does not just reflect the parties' general views on crime, but rather the multi-dimensional nature of political platforms.

The remainder of the empirical analysis focuses on understanding the role of peer effects in jury decision-making. Specifically, we analyze the determinants of an individual nämndeman's actual vote (as opposed to the verdict), taking into account dissenting opinions. Our main specification regresses an individual's vote on the characteristics of their nämndemän peers while controlling for case characteristics and nämndemän fixed effects. In this way, we take advantage of the fact that the same nämndemän are observed with different peers to identify how a given nämndeman's vote responds to their peers.

We find strong evidence of peer effects on juror votes, with nämndemän from both the far-left and far-right parties drawing the votes of their more centrist peers (especially those with more limited experience) towards their own positions. A key remaining question, however, is whether the peer effects that we detect actually affect trial outcomes. In particular, we seek to distinguish between sway effects, where jurors from extreme parties change the votes of their peers by actually changing their point of view, and dissent aversion, where non-pivotal voters change their votes simply to ensure a unanimous decision. In the former case, the swayed jurors' vote can actually have a decisive impact on the case outcome while peer effects that operate through dissent aversion are inconsequential to the verdict.

To disentangle these potential channels, we conduct a novel simulation exercise that uses the results of our analysis to simulate verdicts in a world without peer effects - i.e., one in which individual jurors only affect verdicts through their impact on the majority. Comparing these simulated verdicts to actual trial outcomes leads to several conclusions. First, the majority of the impact of adding Vänsters and, especially, Swedish Democrats to juries comes from the direct effect of their votes (i.e., because they are pivotal voters) rather than from peer effects. Second, dissent aversion plays a clear role in juror voting, as there are substantially 
more unanimous verdicts in the real world data compared to the simulated data. Finally, and most importantly, we decompose the estimated peer effects into sway effects and dissent aversion. For the far-left Vänsters, at least one-third of the total estimated peer effect operates as a sway effect, implying that Vänsters often influence the votes of their closest centrist colleagues in a way that is decisive. In contrast, sway effects account for a negligible portion of the peer effect for far-right Swedish Democrats, implying that they rarely influence their colleagues in a way that actually affects trial outcomes.

The remainder of the paper proceeds as follows. Section 2 provides background on the Swedish nämndemän system and uses survey data to characterize Swedish politics. Section 3 discusses the data. Section 4 presents the empirical methodology, tests of the identifying assumption that nämndemän assignment to cases is random, and the main analysis of the defendant by case level data. Section 5 explores the mechanisms underlying the main results and includes an analysis of peer effects in the individual level data as well as the above described simulation exercise. Section 6 concludes.

\section{Background}

\subsection{Nämndemän (Lay Judges) in Sweden}

Criminal cases in Sweden are adjudicated in the 48 District Courts. Each court employs a pool of professional judges with varying levels of experience and has an associated pool of nämndemän. In contrast to the U.S., where the jury pool is drawn from the general population, individuals must put themselves forward to become nämndeman. ${ }^{9}$ A nämndäman is appointed to the courts for a four-year term by the municipality or county council after being nominated by a political party. The share of each party in a jurisdiction's nämndemän pool is proportional to the party's representation in that jurisdiction. However, although almost all

\footnotetext{
${ }^{9}$ Almost all Swedish citizens over the age of 18 who do not have criminal records are eligible to become nämndemän; some professionals, such as court employees or attorneys, cannot become nämndemän to avoid a conflict of interest.
} 
nämndemän are politically affiliated, they are not meant to be politically active. It is hard to evaluate the extent to which this is true in reality, but an online search for the nämndemän in our data set suggests that about half of the nämndemän do not currently sit and have not sat in the past on any other political committees while 20 percent sit on just one other committee. To the extent that nämndemän are not generally politically active, this would increase the external validity of our findings to less politically based jury systems. Finally, it is important to note that the nämndemän pool is far from representative of the population. This is particularly true with respect to age; in 2010 , just 16 percent of nämndemän were younger than 45 while 46 percent were older than $65 .^{10}$ The unrepresentativeness and political nature of the nämndemän system, particularly with the growth of more extreme parties like the Swedish democrats, is a growing source of public concern.

A defendant's case (verdict, sentence, and oftentimes, damages) is decided at the main hearing (which is the Swedish equivalent of a trial). ${ }^{11}$ For a criminal case in which imprisonment is a possible sentence, the court is comprised of one professional judge and three nämndemän. If the harshest punishment is a fine, the court is typically comprised of a single professional judge. The analysis in this paper focuses on the former, in which the charges are serious enough to require the presence of nämndemän.

Working as a lay judge typically only requires 10 to 15 days per year; most nämndemän are otherwise employed or retired. In the courtroom, each nämndeman listens to the proceedings and may ask additional questions. After the hearing, the judge and nämndemän discuss the possible decisions, including the verdict and sentence, and express their viewpoints. In contrast to the U.S., verdicts do not have to be unanimous, and each lay judge's opinion carries equal weight as that of the presiding judge. If all members of the court are not

\footnotetext{
$10 \mathrm{http} / /$ www.borastingsratt.domstol.se/Om-Sveriges-Domstolar/Pressrum/Nyhetsarkiv/2010/Regeringens-malFler-yngre-namndeman-/

${ }^{11}$ This main hearing occurs for most criminal defendants. In contrast to the U.S. where more than $90 \%$ of cases are pled before trial, even if the defendant admits their guilt, this is typically done in the main hearing.
} 
in agreement, then dissenting opinions are recorded. A defendant is convicted if the majority finds him guilty, even if the presiding professional judge believes he should be acquitted.

\subsection{Additional Details About Gothenburg and The Gothenburg District Court}

Gothenburg is the second largest city in Sweden, and as such, has a relatively high criminal caseload. While the number of reported crimes in all of Sweden from 2009 to 2011 was 14,906 per 100,000 , the number of crimes in Gothenburg was 18,413 per 100,000 . Relative to the other main cities in Sweden, however, Gothenburg has a relatively low crime rate overall and across crime categories; the number of reported crimes over this period in Stockholm and Malmo, respectively, were 22,078 and 20,834 per 100,000 (Brå, 2012). The Gothenburg District Court had almost 350 nämndemän on the roster in the beginning of 2013, representing nine political parties. The two predominant parties are the Social Democrats and the Moderates, which comprise 32 and 29 percent of the nämndemän pool respectively. The other parties are: (i) the Vänster (left) and Green, which are often in alliance with the Social Democrat party, ${ }^{12}$ (ii) the Folk, Center, and Christian Democrats, which form a coalition with the Moderate party (referred to as the Center-Right Block), (iii) the far-right Swedish democrats, and (iv) the vägvalet, which is a local party that opposes the congestion tax in Gothenburg. ${ }^{13}$

According to the Gothenburg District Court webpage, "Neither a professional judge nor a lay judge may choose which cases they adjudicate. The court draws lots to determine who will adjudicate in different cases." Thus, in contrast to the 'de-selection' of the U.S. jury

\footnotetext{
${ }^{12}$ Though the green party is not officially part of the left or right block, many voters do consider them to be left.

${ }^{13}$ There are similarities and differences in the distribution of political parties across the three main cities. Of particular emphasis in this paper are the far right and far left parties. Gothenburg is not an anomaly with respect to these parties. After the 2010 election, vänsters held approximately $7 \%, 9 \%$ and $8 \%$ of the seats in the municipality councils in Malmo, Gothenburg, and Stockholm respectively; greens held approximately $8 \%, 11 \%$, and $16 \%$ respectively; and Swedish democrats held approximately $12 \%, 4 \%$, and $0 \%$ respectively. After the 2014 election, however, even Stockholm had enough Swedish Democrat voters to be represented with a 6\% share on the council, compared to $7 \%$ and $15 \%$ in Gothenburg and Malmo, respectively. In terms of the main parities, Malmo and Gothenburg are historically social democrat strongholds while Stockholm is a moderate party stronghold.
} 
through voir dire, there is meant to be a random nature to the assignment of nämndemän to cases. If such randomness exists, then the characteristics of the nämndemän and judge should be unrelated to the characteristics of the case; we directly test this in the data in Section 4.

How specifically does the roster of more than 300 nämndemän get assigned to cases? Upon election, each nämndeman fills out a form indicating availability for each day of the week. Nämndemän coordinators allocate each nämndeman 15 dates in the upcoming year, taking into account the typical caseload on a given day; for instance, a typical assignment would be every third Tuesday. Importantly, nämndemän are assigned dates far in advance of any knowledge about the cases to be tried on those dates. For each pool of nämndemän assigned to a given day, the coordinators then form triplets; each nämndeman assigned to the same triplet is meant to have the same schedule and sit on cases together in the upcoming year. In practice, however, there is more than expected variation in the composition of the triplets due to the use of substitutes because of either sick (or otherwise unavailable) nämndemän or a higher caseload on a given day than anticipated. While we do not have explicit data on nämndemän absences, one should note that these cannot be correlated with case characteristics, such as offense type, since nämndemän do not know the case until arriving at the courthouse. At the end of the year, new dates are assigned and triplets are adjusted to account for changing schedules. The fact that the data spans the 2010 election provides additional variation in triplet composition.

The formation of triplets is done with some attempt to balance gender (e.g. no all female triplets), age, and political party. With respect to party, the coordinators try to assign different parties to a triplet, which is not always feasible given the high share of Social Democrats and moderates. ${ }^{14}$ Finally, the coordinators assign triplets to those courtrooms scheduled to be in session. For the most part, this is done by going down the list of triplets in order, as each

\footnotetext{
${ }^{14}$ They try to assign one nämndeman to each triplet who has been identified as having special juvenile qualifications, such as being a school teacher. Finally, they ensure that personally connected nämndemän, e.g. married, are not on the same triplet.
} 
triplet has a number associated with it, without taking into account the characteristics of the case or nämndemän. That is, the first triplet is assigned to the first courtroom, the second to the second courtroom, etc. The only exception is for the most serious charges of murder or rape, in which case the coordinators try to assign triplets with some prior experience. Until they arrive at the courthouse, nämndemän do not know what case, or judge, they will see. ${ }^{15}$

\subsection{Political Party Platforms}

To provide some context about Swedish politics, this section analyzes two surveys. The VU Election Survey (Valundersökning), conducted by the SOM-institute at the University of Gothenburg at every general election, is a random sample from Statistics Sweden's population registry of 18-80 year olds who are eligible to vote and residing in Sweden (Holmberg and Oscarsson, 2012). In 2010, 2,736 individuals were interviewed in total, though only 1336 had full-scale interviews. The second survey is the Riks-SOM, which is an annual nationwide postal survey of a random sample of 16-85 year olds residing in Sweden. The survey is split into three editions, focusing on (i) society and politics, (ii) media and culture and (iii) lifestyle and health. The 2010 survey round had 5,007 respondents (SOM-institute, 2011).

The first order question is how each party, on average, views the criminal justice system. We focus in the VU survey on questions related to the support of longer prison sentences and more law and order and in the Riks SOM survey on whether the courts give reasonable punishments. Table 1 presents the results of regressing a respondent's responses to these questions (coded as categorical variables) on party affiliation and controls for age, gender, citizenship, education, and urbanicity. Relative to Social Democrats, Vänsters (greens) are 15 (19) percentage points less likely to favor harsher prison sentences, 13 (14)

\footnotetext{
${ }^{15}$ The description of the nämndemän assignment process characterizes the system as of March 2010, when a new system was implemented. This occurred at the same time as the merging of the Göteborg and Mölndal district courts. Prior to this date, judges sat with one of two sets of triplets for a given day; that is, the nämndemän regularly came into contact with the same judges.
} 
percentage points less likely to favor more law and order, and 16 (17) percentage points more likely to oppose harsher prison sentences. In contrast, Swedish Democrats are 24 percentage points more likely to favor harsher sentences, 28 percentage points more likely to favor more law and order, and 26 percentage points more likely to think that the courts give unreasonable punishments. These results are surprisingly insensitive to including controls and even additional controls for how left/right respondents perceive themselves; they appear to say something about party rather than other individual characteristics that may be related to party.

Thus, the available survey evidence suggests that the left and green parties are, on average, relatively soft on crime while Swedish Democrats are hard on crime: these parties generally fall on opposite ends of the spectrum, with all other parties somewhere in the middle. This is very much consistent with anecdotal evidence and popular perceptions. In fact, the Swedish Democrat platform advocates the use of real life sentences without parole; under the current system, life sentences usually imply 18 years (and parole after 12 years).

Given the multi-faceted nature of both politics and criminal cases, it is perhaps too narrow-minded to only consider a party's attitude towards crime. Other issues that may play prominent roles are feminism and nationalism/immigration. In fact, one of the primary platforms of the Vänster party is as a feminist party; according to the party's manifesto: "The superiority of men and subordination of women is no law of nature. The struggle for women's rights has yielded significant results. Feminism gives arguments and tools for the women's struggle that must be waged to break the power of the patriarchy. This struggle is carried out in politics and in the workplace, but also in private life." ${ }^{16}$ This paper will assess whether the struggle is also carried out in the courtroom. Empirical evidence of the Vänster party feminist

\footnotetext{
${ }^{16}$ Translated by the author: "Mäns överordning och kvinnors underordning är ingen naturlag. Kampen för kvinnors rättigheter har givit viktiga resultat. Feminismen ger argument och redskap för den särskilda kvinnokamp som måste föras för att patriarkatets makt skall kunna brytas. Denna kamp förs inom politiken och arbetslivet, men också i privatlivet.” http://www.vansterpartiet.se/material/partiprogram/
} 
platform is provided in Table 1; Vänster party members are 17 (15) percentage points more likely than social democrats to strongly support gender equality in the VU (SOM) survey.

In addition, similar to other far right parties throughout Europe, Swedish Democrats largely run on a nationalist, anti-immigration platform. ${ }^{17} \mathrm{~A}$ quote from their party website clearly demonstrates their views: "In recent decades, Sweden has accepted too many immigrants in too short a time. ... This reckless policy has created impoverished and marginalized areas around the country. Areas which, when they were originally built, were regarded as fine middle-class neighborhoods have turned into segregated areas where unemployment and crime is high." 18 These views are apparent in the SOM questions on whether immigrants are punished harsher than non-immigrants. Swedish Democrats are more than 30 percentage points more likely than Social Democrats to think that immigrants are not punished more harshly; Vänsters, in contrast, are 13 percentage points less likely to think that immigrants are punished more harshly (consistent with their anti-racism position).

\section{Data}

\subsection{Data Description}

The data is based on a sample of closed crimes against person cases for the Gothenburg District Court for 2009 through 2012. Specifically, we obtained all cases (almost 400) with at least one charge of murder, rape, robbery, manslaughter, sexual assault, and aggravated assault (or an attempt) during this period. Given the time intensive nature of manually coding all data, we requested a random sample of almost 200 (of 400) unlawful threat cases and 400 (of 1500) simple assault cases. As all of these violent offense charges have imprisonment on

\footnotetext{
${ }^{17}$ These include, for instance, the National Front Party in France, the Golden Dawn Party in Greece, the Flemish Interest Party in Belgium and the Danish People's Party in Denmark.

${ }^{18}$ Translated by the author: "De senaste decennierna har Sverige tagit emot allt för många människor på allt för kort tid. ... Denna ansvarslösa politik har gjort att det ständigt skapats växande utanförskapsområden runt om i landet. Områden som när de byggdes betraktades som fina medelklasskvarter har förvandlats till segregerade områden där arbetslösheten och brottsligheten är hög."https://sverigedemokraterna.se/var-politik/vara-viktigastefragor-2/invandring/
} 
the table, they were tried by a professional judge and three nämndemän. ${ }^{19}$ The resulting data set includes 956 cases and, due to multiple defendant cases, 1152 unique defendant-case observations. Just 28 defendants appear in the data more than once.

Two documents for each case number were obtained from the Gothenburg District Court Archive: Anteckningar (notes) and Dom (Judgement) ${ }^{20}$ For each case, we extracted the nämndeman and judge names as well as trial dates times from the Anteckningar. From the Dom, we extract information about the defendant(s), offense(s) charged, case, and verdict. Defendant information includes name, country of citizenship, and personal identity number, from which we can identify birth date and gender. Though we do not know ethnicity, we have coded defendant names as having distinctly Arabic sounding names (all of the 255 defendants coded as such have Arabic sounding first and last names). We do recognize that not all of these defendants are actually Arabic, but may simply have names 'similar' to Arabic names. We cannot distinguish these two groups of individuals in the data; however, the same may be true for the nämndemän who are deciding their cases. We also coded two additional categories of defendant names: (i) distinctly Swedish and (ii) other (which contains, but is not limited to, many Eastern European names, as well as those that are difficult to otherwise classify). ${ }^{21}$

The case and verdict information includes the victim's name(s), attorney names, the charges on which the defendant was acquitted or convicted, damages requested and awarded, and the sentence. The most common sentences are fine, probation, imprisonment, suspended sentence, and community service. Juveniles can be sentenced to community service or the child welfare authorities; youths under 18 are generally not eligible for adult prison sentences.

\footnotetext{
${ }^{19}$ Because the Court could not directly identify nämndemän cases, the data request conditioned on offense categories guaranteed to be eligible for prison, regardless of criminal history. This immediately excludes many property crimes, which are sentenced with fines.

${ }^{20}$ A handful of requested cases were not included in the final data because of missing documents in the archives.

${ }^{21}$ We cross-check the coding of names by looking at the number of individuals with the same name (first or last) throughout Sweden. http://svenskanamn.alltforforaldrar.se/statistik/sverige
} 
From a description in the Dom of the evidence presented, we determine whether the defendant fully or partially admits guilt; partial admission implies that the defendant admits some aspects/circumstances of the incident. The Dom also describes the criminal history of convicted defendants; we code the number of previous episodes in the crime registry, whether there are any violent offenses, and, when available, the date of the last sentence. For acquitted individuals, we obtain this information from an additional document (belastingsregistret) from the archives. Finally, the Dom includes a description of any dissenting opinions (skiljaktig mening) amongst the judge and/or nämndemän in the verdict and sentence.

We merged this case by defendant level data with a data set that we created of nämndemän and judge characteristics. ${ }^{22}$ The primary variables identified for nämndemän included municipality, gender (based on name), birth year, first year as a nämndeman, and political party. Though we do not have a measure of nämndeman ethnicity, we have coded individuals as having names that are non-Swedish. With respect to judges, we have data on age and gender from the district court. There are 93 unique judges in our data, though just 37 judges are assigned to ten or more cases.

\subsection{Descriptive Statistics}

Table 2 provides descriptive statistics characterizing the defendants, case characteristics, verdicts and sentences, judges, and nämndemän triplets. We begin with the variable of interest - nämndemän triplets. Despite the facts that nämndemän are assigned to triplets that should 'ordinarily' serve together and there are a little more than 100 such triplets at any given time, 793 unique triplets are observed in the data set. This variation arises from (i) a substantial change in the nämndemän roster after the 2010 election, (ii) annual adjustments to account for changes in schedules, and (iii) substitute nämndemän due to unscheduled absences or an

\footnotetext{
${ }^{22}$ These data were compiled from a number of sources, including the Gothenburg district court for the current nämndemän roster and communications with each municipality (and/or their websites) in the Gothenburg district court catchment area for nämndemän on the roster prior to the 2010 election.
} 
unexpectedly high caseload. Table 2 shows that the majority of nämndemän in the triplet are male in 46 percent of the observations, the average nämndemän age in a triplet is 58 , and 83 percent of defendants face triplets where the average age is older than 50. In terms of experience, $17,36,24$, and 23 percent of defendants face triplets with less than two, two to four, four to six, and more than six years of experience, respectively. Finally, 40 percent of triplets have at least one nämndeman with a non-Swedish name. ${ }^{23}$

In terms of political affiliations, Table 2 shows that 74 and 69 percent of triplets have at least one Social Democrat and Moderate, respectively. With respect to the other parties, we see that 27 and 20 percent, respectively, have members of the Green and Vänster parties (both of which sometimes cooperate with the Social Democrats). For the parties closely aligned with the Moderates, we see that 29, 13, and 2 percent have at least one Folk, Christian Democrat, and Center party member, respectively. A Swedish Democrat is in the triplet in nine percent of observations.

Turning to the defendants and cases, Table 2 shows that 91 percent of defendants are male, 12 percent are not Swedish citizens, 22 percent have an Arabic sounding name, and the average defendant age is 32 . 36 percent of defendants have at least one past conviction and 20 percent have at least one violent conviction. Cases have, on average, 1.7 defendants $(74 \%$ of observations have just one defendant), 1.5 victims ( $71 \%$ have just one victim), and 1.9 charged offenses ( $57 \%$ have just one offense). 50 percent of the observations have at least one female victim, where victim gender was determined by victim name or the pronouns used in the transcript for cases with anonymous victims (e.g. some sex related offenses). In 9 percent of observations, the defendant fully admits guilt, i.e. on all charges, while 44 percent of defendants fully deny guilt. 46 percent of defendants are coded as partially admitting guilt;

\footnotetext{
${ }^{23}$ Non-Swedish names are quite distinct from Swedish ones, and typically have Arabic or Eastern European origins. This variable was created by a Swedish research assistant; we have also assessed the validity of his assessment by looking at the relationship between the number of Swedes with the same first name and last name as each nämndeman.
} 
they have either admitted guilt to one offense but not another, or they have admitted some of the aspects of the charge but do not take full responsibility (e.g. he admits to hitting him, but it was in self-defense). The conviction analyses exclude cases where guilt is fully admitted, as there is no room for discretion.

Current offense charges are grouped into nine categories; 28 percent of the observations include an offense that does not fall into one of these categories. Though the data were created using a 'crimes against person' selection criterion, other offenses appear in multi-charge cases. The most common offenses are: assault (56\% have at least one assault charge), unlawful threat $(26 \%)$, aggravated assault $(13 \%)$, rape $(8 \%)$, robbery $(5 \%)$, drug charges (11\%), and other sex offenses (7\%).

The primary outcome considered in this paper is conviction. Table 2 shows that 83 percent of charges result in a conviction and 88 percent of defendants have at least one conviction; these statistics are substantially smaller (75 percent and 77 percent, respectively) when conditioning on the almost 500 defendants who fully deny guilt, i.e. when there is presumably more room for discretion. Though not the focus of the paper, we see that 30 percent of all convicted defendants are sentenced to prison; 35 percent of those who are older than 18 and eligible for adult prison receive such a sentence. ${ }^{24}$

Eight percent of observations have at least one dissenting opinion (about three percent from a professional judge and five percent from at least one nämndeman). Five percent of observations have a dissenting opinion in favor of a harsher outcome, while three percent favor a more lenient outcome. The dissenting opinion data will be used when we create the individual nämndemän level data set described in Section 5. Finally, the average age of judges is 50 years old and 55 percent are male. We include judge fixed effects in almost all specifications to account for these and other judge characteristics.

\footnotetext{
${ }^{24}$ Note that in Sweden, defendants under the age of 18 are not eligible for an adult prison sentence, while there is some discretion for those between the ages of 18 and 21 . There is no discretion for defendants above the age of 21.
} 


\section{Main Case by Defendant Level Analysis}

\subsection{Methodology and Identification}

The first part of the empirical analysis uses the defendant by case level data set described above to examine the relationship between nämndemän triplet political affiliations and case outcomes. To this end, the basic empirical specification is as follows:

(1) $Y_{i j}=\propto+\beta_{1}$ Vänster $_{j}+\beta_{2}$ Green $_{j}+\beta_{3}$ SwedishDem $_{j}+X_{j} \gamma+Z_{i j} \pi+\lambda_{\text {judge }}+\varepsilon_{i j}$, where $Y$ represents the outcome (e.g. share of charges resulting in conviction) for defendant $i$ associated with case $j$. Vänster, Green, and SwedishDem are dummy variables indicating if at least one of the nämndemän in the triplet belongs to each of these far left or right parties, respectively. We choose to focus our specification on these extreme parties rather than all parties because this is where the interesting variation is in the composition of the triplets, as almost all triplets have a social democrat and moderate block member. It is important to note that controlling for the other parties has little impact on the results (as will be demonstrated later); thus, excluding them from the main analysis greatly eases the exposition, particularly for those specifications with many interactions. $X$ represents a vector of other nämndemän triplet characteristics, including the average age and experience of the triplet, an indicator for whether the majority of the triplet is male, and an indicator for whether the triplet contains at least one member with a non-Swedish name. Finally, $Z$ represents a vector of 20 offense, case and defendant characteristics and $\lambda_{\text {judge }}$ represents judge fixed effects.

For the $\beta$ 's to represent a causal effect of nämndemän political affiliations on case outcomes, nämndemän triplets must be randomly assigned to cases, or at least randomly assigned conditional on known assignment factors. Because the nämndemän coordinators randomly assigned nämndemän triplets to courtrooms, the characteristics of the triplet should 
be unrelated to the characteristics of the defendant and case. Thus, Columns (1) - (10) of Table 3 assess whether there is evidence of non-random assignment of triplets to cases by regressing ten triplet characteristics (party, gender, non-Swedish name, average age, average experience) on four defendant characteristics (gender, age, citizenship, and Arabic sounding names), eleven offense characteristics (number of charges and ten offense category dummies), five case characteristics (full and partial admission, number of defendants, number of victims, any female victims), and two criminal history measures (any past convictions and any violent past convictions). We summarize the results by conducting F-tests of the joint significance of the controls in each of these categories, counting the number of coefficients significant at the $5 \%$ level in each regression, and presenting the R-squared.

Of the 40 F-tests conducted (four tests for 10 regressions), just two are significant at the five percent level - the offense characteristics in column (3) for Christian democrats in the triplet and the case characteristics in column (5) for Swedish democrats in the triplet. However, the joint significance of both of these tests is driven by the significance of just one coefficient. In fact, in nine of the ten regressions, there are just two (or fewer) significant coefficients. There are four significant coefficients when looking at average experience of the triplet, though just one of the joint F-tests are significant at the ten percent level; if there were to be non-random assignment in any dimension, it would be with respect to triplet experience given statements by the nämndemän coordinators about trying to assign triplets with experience to the most serious cases. Finally, this large set of 22 case characteristics explains very little of the variation in triplet characteristics; the R-squared ranges from 0.016 to 0.037 .

Columns (11) and (12) of Table 3 test for the random assignment of judges to cases and nämndemän triplets. We regress judge gender and age on the same sets of case characteristics included in the previous specifications plus two sets of variables characterizing the political affiliations and other characteristics of the nämndemän triplet, respectively. None of the joint 
tests of nämndemän characteristics are significant: consistent with courthouse discussions, nämndemän triplets do not appear to be assigned to courtrooms on the basis of the judge assigned to the case. In terms of the random assignment of judges to case characteristics, we see four significant coefficients in the judge gender specification and an R-squared of 0.072; none of the coefficients are significant at the five percent level for judge age. These results are consistent with courthouse statements that judges are assigned to cases according to a roster, with some load balancing and with certain cases requiring more senior judges.

Taken as a whole, the results presented in Table 3 are strongly indicative of the random assignment of nämndemän triplets to cases and judges. However, it should also be emphasized that to the extent there is not random assignment, we control for almost all potentially confounding factors with judge fixed effects and the same set of nämndemän characteristics that the coordinators have at their disposal. Finally, as shown below, the insensitivity of our results to the inclusion of these controls is also consistent with random assignment.

\subsection{Baseline Results}

Table 4 presents the results of estimating equation (1) with the full set of controls; only the coefficients on the variables of interest (having at least one Vänster, Green, or Swedish Democrat in the triplet) are presented. The dependent variable is the share of current charges resulting in conviction in columns (1) and (2) and whether any charge results in conviction in columns (3) and (4). Two key results emerge. First, having a hard-on-crime Swedish Democrat in the triplet does not affect the likelihood of conviction. Second, having a soft-oncrime Vänster in the triplet, if anything, increases the likelihood of conviction by more than five percentage points when looking at cases where the defendant did not fully admit guilt (columns (1) and (3)) and by more than 13 percentage points when looking at cases where the 
defendant completely denied guilt and there is arguably more discretion (columns (2) and (4)). Note that controlling for the other, more central parties, in this regression has little impact on the results for the extreme left and right parties; in addition, these other parties also do not significantly affect conviction rates.

The specifications presented in Table 4 implicitly assume that juror political party has the same impact on every case, regardless of the characteristics of the defendant or case. Given the multi-dimensional nature of party platforms, however, this is a very strong assumption. To explore the impact of political party in a more nuanced way, Table 5 expands the specification to include an interaction of each party variable with a series of defendant/case characteristics: whether there are any female victims in column (1), whether the defendant has an Arabic name in columns (2) and (3), and whether the defendant is younger than 21 years old in column (4). ${ }^{25}$ The choice of case characteristics is based on key aspects of the political party platforms and what is available in the data. For readability, we only show results for the presence of Swedish Democrat and Vänster nämndemän; Green party affiliation is included (and appropriately interacted) in all specifications.

Some striking patterns emerge. First, the Vänster effect suggested in Table 4 is driven by cases with a female victim. Specifically, Column (1) shows that having a Vänster in the triplet when there is a female victim increases the share of current charges resulting in conviction by about 14 percentage points; this is significant at the 1 percent level. ${ }^{26}$ On the other hand, when the victim is male, having a Vänster in the triplet does not have a significant impact. $^{27}$

\footnotetext{
${ }^{25}$ Age twenty-one is chosen as a natural cutoff given the differential treatment (with respect to sentencing options) of defendants above and below that age.

${ }^{26}$ Here we are describing the results for the total effect of adding a Vänster in cases in which the victim is female - i.e., summing the coefficient on any_vänster and any_vänster*any_femalevic and characterizing whether that coefficient is significantly different than zero. We follow this approach for reporting results throughout this section of the paper.

${ }^{27}$ To further understand these results, we have also categorized vänsters as older $(>50)$ and younger $(<50)$. Perhaps surprisingly given that the feminist vänster platform emerged in the last 30 years, we see that it is only triplets with vänsters who are older that are significantly more likely to convict when there are female victims.
} 
Second, Column (2) shows that having a Swedish Democrat in the triplet increases the share of current charges resulting in conviction for defendants with Arabic names by 17 percentage points, a result which is significant at the 5 percent level. Adding a Swedish Democrat to the triplet has no significant impact when the defendant has a non-Arabic name. Column (3) repeats the specification in Column (2) but excludes defendants with non-Arabic and non-Swedish names (such that Arabic named defendants are compared directly to just Swedes, rather than those of other ethnic origins); the results are similar. These results are consistent with the Swedish Democrats' nationalist, anti-immigration platforms. They are also consistent with Marten's (2015) recent finding that asylum appeals in Sweden are more likely to be rejected when there is a Swedish Democrat on the triplet.

Finally, Column (4) indicates that adding a Swedish Democrat to the triplet increases the share of current charges resulting in conviction for defendants that are younger than 21 by 16 percentage points $(-0.079+0.239)$, with an associated p-value of 0.008 . While the Swedish Democrat party platform does not explicitly take a position regarding the treatment of youths in the criminal justice system, these results are consistent with other aspects of the party platform including those related to schooling and personal responsibility. Taken together, the results in Columns (1)-(4) suggest that it is important to take into account the multi-dimensional nature of party platforms when examining how political affiliations might affect conviction decisions, as opposed to only considering the party's general stance on crime.

In addition, it is important to note that the basic pattern of results seen for these extreme parties in Table 5 is robust to the inclusion of dummies for each party and the appropriate party by case characteristic interaction. This can be seen in Appendix Table 1, which

Triplets with younger vänsters are insignificantly more likely to convict in all cases. These results are consistent with the VU survey data; older vänsters appear to have more strongly feminist views than younger vänsters. We have also assessed whether it is female or male vänsters driving these results, but we find the same, albeit statistically insignificant, vänster-female victim estimate for both genders. 
replicates columns (1), (2) and (4) from Table 5 for all parties. These less extreme social democrat and moderate block parties generally do not have a significant impact themselves; the only exception is that having a moderate on the triplet increases the conviction rate for female victim and young defendant cases, though these relationships are only marginally significant.

The central results presented in the first four columns of Table 5 are robust to a number of alternative specifications. In Table 5, Columns (5)-(7) repeat the specifications in Columns (1), (2) and (4), respectively, but change the dependent variable to an indicator of whether a defendant was convicted of at least one charge; the same pattern of results emerge. And Table 6 demonstrates that the main results are not sensitive to the exclusion/inclusion of the baseline set of controls included in Table 5: defendant, offense, case and nämndemän characteristics and judge fixed effects. Column (1) of Table 6 includes just the main nämndemän political party variables and their simultaneous interactions with the three case characteristics considered in Table 5. ${ }^{28}$ Column (2) adds judge fixed effects, which increases the magnitude of some of the coefficients but does not change the qualitative pattern of results; this is consistent with the results from the previous section suggesting that judges are not perfectly randomly assigned to cases. Controlling for other nämndemän triplet characteristics (gender, age, experience, Swedish name) in column (3) does not affect the results, indicating that it is the nämndeman's party that matters and not another characteristic of nämndemän correlated with party choice. Columns (4) - (7) control for defendant, case, offense, and criminal history characteristics, respectively; the robustness of the results to this large set of controls is again indicative of the random assignment of triplets to cases. Controlling for hearing year and day of week effects in column (8) has no effect and indicates that the results are not being driven

\footnotetext{
${ }^{28}$ Note that because this specification includes all three interactions simultaneously, the coefficients on any_vänster and any_swededem will not be the same as in Table 5. However the same general pattern of results is found among the subgroups of cases (i.e., female victims, Arabic named defendants) when one plugs in the mean level of the variables in the other interaction terms.
} 
by changes in the nämndemän pool and party views on crime over time. Lastly, column (9) indicates that controlling for the 81 prosecutors observed in the data has little effect on the results, suggesting that attorney characteristics are not driving the result. ${ }^{29}$

\subsection{Triplet Majority Composition}

The analysis presented thus far considers only the presence of at least one Vänster or Swedish Democrat in the triplet and does not take into account the composition of the remainder of the triplet. Because some parties are closer to others in terms of political platforms, one might expect the impact on conviction from adding nämndemän from these extreme parties to depend on the remaining composition of the jury. Table 7 examines this by presenting specifications that include an interaction of party affiliations with case characteristics (as in Table 5), and an additional interaction with whether the majority of the triplet is from a party that is considered to be on the left of the political spectrum (i.e., the left alliance of Social Democrats, Greens, and Vänsters). Column (1) repeats the baseline result shown in the first column of Table 5, showing that having a Vänster in the triplet increases the share of charges convicted by almost 14 percentage points when there is a female victim. Column (2) indicates, however, that this effect is driven by cases in which the majority of the triplet is from the left/social democrat alliance. Columns (3) and (4) present the results for the Arabic-named defendants specifications. Having a Swedish democrat in the triplet increases (substantially) the share of charges convicted for an Arabic sounding named defendant, regardless of whether the majority composition is from the left/social democrat alliance. Finally, columns (5) and (6) indicate that having a Swedish Democrat in the triplet increases

\footnotetext{
${ }^{29}$ This specification rules out, for example, that the Vänster-female victim result is driven by the fact that Vänster prosecutors can present a more persuasive case to a triplet with a Vänster nämndeman. Controlling for fixed effects for the 232 defense attorneys (a demanding specification given there are only about 1000 observations) has little qualitative impact; however, there is some loss of precision for a couple of estimates and some changes in the coefficient magnitudes (some larger and some smaller).
} 
the share of charges convicted for young defendants, regardless of the majority composition of the triplet.

\section{Peer Effects in the Deliberation Process}

The previous section documented two key results: (i) having a Vänster in the triplet increases convictions when there is a female victim and (ii) having a Swedish Democrat in the triplet increases convictions when there is an Arabic-named defendant. The most obvious way in which adding these nämndemän from the far left and right parties can have an impact on verdicts is that their vote simply shifts the majority opinion in the case towards their viewpoint. We term this the direct effect. However, it is also possible that in addition to having a direct effect, these nämndeman also influence the votes of their peers. The unique structure of the Gothenburg District Court, whereby the same nämndeman sits on numerous court cases with different peers in their triplet, allows us to explicitly determine whether peer effects are present. Section 5.1 discusses our identification strategy in more detail and shows empirical evidence that Vänsters and Swedish Democrats impact the votes of their peers in cases with female victims and Arabic-named defendants, respectively. Section 5.2 examines whether there is heterogeneity in peer effects. Finally, in Section 5.3, we consider whether jurors are only changing their votes to avoid dissent in cases in which their vote would not be pivotal or whether peer effects affect decision-making in a way that actually impacts trial outcomes.

\subsection{Measuring Peer Effects}

The goal of this section is to determine whether a nämndeman's vote is affected when they are seated in a triplet with either a Vänster or Swedish Democrat nämndeman. To do this, we transform the defendant level data set that we have been using into an individual nämndemän- 
defendant data set. That is, each observation in the original defendant data set now represents three (nämndemän) observations in the new data set associated with each nämndemän's verdict. ${ }^{30}$ Recall that since verdicts do not need to be unanimous, the three nämndemän who sit on the same case may vote differently with respect to whether to convict. In reality, however, less than 2 percent of nämndemän dissent. ${ }^{31,32}$

Equation (2) presents the basic specification we use to identify peer effects:

(2) $Y_{n i j}=\propto+\beta_{1}$ VänPeer $_{n j}+\beta_{2}$ SwDemPeer $_{n j}+$ OthPeerChar $_{n j} \delta+Z_{i j} \pi+\lambda_{\text {judge }}+\alpha_{n}+\varepsilon_{n i j}$,

where $Y$ represents the share of charges on which nämndeman $n$ assigned to case $j$ with defendant $i$ votes to convict. VänPeer ${ }_{n j}$ and $S w$ DemPeer $_{n j}$ are indicator variables for whether any of nämndeman $n$ 's peers on case $j$ are members of the Vänster or Swedish Democrat parties, respectively. OthPeerChar ${ }_{n j}$ contains an indicator for whether any of nämndeman $n$ 's peers on case $j$ are members of the Green party, as well as a vector of other peer nämndemän characteristics (e.g. age, gender, experience). As above, $Z$ is a vector of case and defendant

\footnotetext{
${ }^{30}$ Note that there are some nämndemän for which information on background characteristics, particularly age and experience, is missing. So as to not decrease the sample size in the main case level analysis, nämndemän triplet characteristics were based on the average for those nämndemän on the triplet for which this information is observed. In the individual level analysis, we omit those observations with missing own nämndeman characteristics, so there are some cases from the main data set that only translate into two nämndemän level observations. As can be seen in the simulation exercise in the next sub-section, however, the baseline results are not sensitive to the exclusion of cases for which nämndeman background characteristics are not known for all three nämndemän on the triplet.

${ }^{31}$ The fact that there are so few dissents suggests that some of the potential peer effects we might find are due to dissent aversion. This will be explicitly discussed in Section 5.3.

${ }^{32} \mathrm{We}$ examine the determinants of individual nämndeman dissents more closely in Appendix Table 2. Specifically, we regress whether the nämndeman dissented from the verdict for at least one offense on a vector of own nämndeman characteristics, a vector of peer characteristics, and the full vector of defendant and case characteristics. Columns (1) and (2) present the results for nämndemän from parties considered to be to the right in the political spectrum (members of the moderate block and Swedish Democrats) and to the left (Vänster, Green and Social Democrats), respectively. The results show that few variables are significantly related to dissenting. However, one does see that sitting with extreme peers from the same side of the political spectrum as oneself significantly decreases the likelihood of dissenting: 'right' and 'left' nämndemän sitting with Swedish democrat and vänster peers, respectively, are less likely to dissent. In contrast, sitting with extreme peers from the opposite end of the political spectrum as oneself (i.e. 'left' nämndemän with Swedish democrat peers and 'right' nämndemän with vänster peers) increases the likelihood of dissenting; though the point estimates are as large as those for peers on the same side of the spectrum, they are insignificant. These relationships are not affected when controlling for interactions between case characteristics (female victim, Arabic defendant, young defendant) and peer extreme parties.
} 
characteristics and $\lambda_{\text {judge }}$ represents judge fixed effects. Finally, $\alpha_{n}$ represents nämndeman fixed effects. All standard errors in the individual analysis are clustered at the case level.

Using nämndeman fixed effects implicitly focuses on the variation within the cases on which a given nämndeman sits, measuring how their vote is affected when they sit with a far left Vänster $\left(\beta_{1}\right)$ or far right Swedish Democrat $\left(\beta_{2}\right)$ relative to when they sit with more centrist peers. As long as a given nämndeman's pairing with a Vänster peer or a Swedish Democrat peer is uncorrelated with defendant and case characteristics, $\beta_{1}$ and $\beta_{2}$ will identify causal peer effects. Importantly, even though nämndemän themselves are not fully randomly assigned to each other in order to balance triplets based on gender, age, and political party, the pairing of nämndeman with each other appears to be independent of case and defendant characteristics. The latter statement is borne out in the results presented in Table 3 , which show that the composition of the triplet is largely unrelated to case and defendant characteristics. Further, in results not shown, we regress the characteristics of a given nämndeman's peers (such as whether they have a Vänster peer, etc.) on case and defendant characteristics along with nämndeman fixed effects. The overall pattern of results is similar to Table 3 in that there are very few significant coefficients. ${ }^{33}$

Table 8 presents the results of estimating equation (2). Because we would expect Vänsters and Swedish Democrats to exert peer effects in the cases for which they have distinctly different viewpoints, we accordingly test for the presence of peer effects separately for these subsamples. Specifically, columns (1)-(2) present the results from estimating equation (2) separately for cases with and without female victims; cases with and without Arabic-named defendants are in columns (3)-(4), and cases with younger $(<21)$ and older defendants are in columns (5)-(6). For brevity, we only report the $\beta_{1}$ and $\beta_{2}$ coefficients associated with peer effects. The results in Column (1) indicate that for female victim cases,

\footnotetext{
${ }^{33}$ The fact that nämndemän are assigned to each other in order to provide gender, age and political party balance in the triplets will have implications when we look at the heterogeneity of peer effects; we discuss this further in Section 5.2.
} 
sitting with a Vänster peer increases the share of charges on which a nämndeman votes to convict by 13 percentage points versus when they sit with a more centrist peer. Column (2) reveals that there is no effect of having a Vänster peer in non-female victim cases. Likewise, Columns (3) and (4) reveal that having a Swedish Democrat peer increases the share of convictions for cases with Arabic-named defendants, but has no effect for defendants with non-Arabic names. Column (5) shows that for cases with young defendants, having a Swedish Democrat peer increases the share of charges convicted, although the effect is not significant; Column (6) reveals that among cases with older defendants, the presence of a Vänster peer increases the share of charges on which a given nämndeman convicts. Overall, the results from Table 8 provide strong evidence of peer effects for the cases in which Vänsters and Swedish Democrats were identified to have distinctly different opinions. Furthermore the peer effects these more extreme parties exert are consistent with their direct effect on trial outcomes.

One final note to the above conclusion is that while so far we have made the plausible assumption that Vänsters and Swedish Democrats do themselves exert a direct effect, we show explicit evidence of this in Appendix Table $3 .{ }^{34}$ The analysis in this table exploits the fact that we observe different nämndeman sitting with the same set of peers to identify the effects of a nämndeman's own political party on their decision to convict. ${ }^{35}$ These results firmly establish that both Vänsters and Swedish Democrats are themselves more likely to vote to convict in cases with female victims and Arabic-named defendants, respectively.

\subsection{Are Peer Effects Heterogeneous?}

\footnotetext{
${ }^{34}$ Note that if there were no direct effect, the overall impact of adding a Vänster or Swedish Democrat would come about solely because other parties became more likely to convict when they sat with these extreme party members.

${ }^{35}$ Specifically, we regress an individual nämndeman's vote to convict on a vector of dummies that capture the nämndeman's own party affiliation, judge fixed effects, the full set of case controls, and peer fixed effects.
} 
The previous section documented that Vänsters and Swedish Democrats affect the votes of their peers in a way that is consistent with the platforms of these more extreme parties. The next natural question is whether they have more of an effect on some peers than others. As one might expect the degree of peer influence to depend on both the demographics and the political party characteristics of the nämndemän, we examine both of these in turn.

Table 9 examines whether peer effects are heterogeneous across nämndemän with different demographic characteristics. Each column considers a different sub-sample of nämndemän, characterized by their gender, age, and experience. Each panel estimates the basic peer effect specification presented in equation (2), but also interacts the peer party variables with a case characteristic (female victim cases in Panel A, Arabic named defendants in Panel B, and young defendants in Panel C). Though all peer party variables are interacted with the relevant case characteristic, we only present the coefficients for the variables of interest; e.g. Vänster peers in female victim cases and Swedish democrat peers in Arabic named defendant cases.

The results presented in Table 9 suggest the existence of heterogeneous peer effects. For female victim cases, the effect of having a Vänster peer appears to have a qualitatively similar impact across these groups of nämndemän, but with the hint of stronger effects for younger, less experienced nämndemän. Similarly, the estimated Swedish Democrat peer effect for Arabic sounding defendant cases is positive in all cases and again greatest in magnitude for less experienced nämndemän. Finally, the results presented in Panel C reveal that among cases with older defendants the presence of a Vänster peer has the largest effect for male and younger nämndemän, while among cases with younger defendants the presence of a Swedish Democrat peer is greatest for the least experienced nämndemän.

Taken as a whole, the results presented in this table indicate that peer effects tend to be strongest among the most inexperienced nämndemän. Note that because the nämndemän 
coordinators form the nämndemän triplets independently of each nämndeman's experience level (i.e., they do not balance based on experience), an inexperienced nämndeman faces a Vänster and Swedish Democrat peer comparable to one that a more experienced nämndeman faces. ${ }^{36,37}$

Table 10 presents the results of expanding equation (2) to include interactions between one's own party and having a Vänster or Swedish Democrat peer. This specification allows us to analyze whether party peer effects vary with an individual's own political position; this might be expected if nämndemän are more influenced by peers from parties that are closer to them in the political spectrum. Recall that the parties line up as follows from left to right: Vänsters, Greens, Social Democrats, the Center-Right block (which includes Moderate, Center, Folk, Christian Democrat, and Vägvalet party members), and the Swedish Democrats; further, Vänsters often tend to politically align with Social Democrats. ${ }^{38}$ Because balancing is done with respect to the political parties of the triplet and the majority of nämndemän do not come from the extreme parties, Vänsters and Swedish Democrats are typically matched up to nämndemän from more central parties (i.e. Social Democrats and members of the CenterRight block). Thus there is not a lot of data to identify the impact of one extreme party sitting with another. ${ }^{39}$ While we present all of the results for completeness in Table 10, we mainly

\footnotetext{
${ }^{36}$ In contrast, when we look among subgroups along which balancing does occur (like gender and age) nämndemän subgroups will be matched up with Vänster and Swedish Democrat peers with different characteristics. For example, female nämndemän would be more likely than male nämndemän to be matched up to a male Vänster peer. Thus if we had found stronger peer effects among females it would have been difficult to distinguish whether females themselves were more influenced by Vänsters, or if male Vänsters were just more influential.

${ }^{37}$ Previous field studies of actual juries have looked at which jurors are the most influential. These studies found that (i) male jurors are more influential on their peers than females (Mills and Bohannon, 1980; Marcus, et. al, 2000), (ii) higher socioeconomic status jurors are more influential (York and Cornwell, 2006), and (iii) more extraverted jurors are more influential (Clark et al, 2007; Marcus et al, 2000). These studies often use small case samples and are based on the 'selected' seated jury. See Devine (2012) for a more thorough review of this literature.

${ }^{38}$ The Vägvalet party is a young, local party specific to Gothenburg, and as such does not have a formal platform on many national issues. However, a recent article characterizes them as mostly voting to the right, and that there party platform is even to the right of the moderate party on some issues. http://www.gp.se/nyheter/goteborg/1.2266983-vagvalet-drar-at-hoger-i-politiken

${ }^{39}$ There are only 15 defendant cases with two Vänsters in the triplet, 20 cases with a Vänster and Swedish Democrat in the triplet, and no cases where there are two Swedish Democrats in the triplet.
} 
focus on the impact that Vänster and Swedish Democrat peers have on Social Democrats and the Center-Right block.

The results in Column (1) indicate that Vänster peers exert influence on both Social Democrats and Center-Right block members in cases with female victims, although the effect is slightly stronger for Social Democrats. Column (2) indicates that among Arabic-named defendant cases Swedish Democrats peers exert their effect on Social Democrats but have no impact at all on the conviction votes of Center-Right block members. Finally, Column (3) shows that among cases with older defendants, Vänster peers exert their effect on both Social Democrats and Center-Right block members, but the effect is slightly stronger on Social Democrats; likewise among cases with younger defendants Swedish Democrat peers exert their effect on both Social Democrat and Center-Right block members but the effect is stronger on Social Democrats. Thus the overall results suggest that both Vänsters and Swedish Democrats exert larger peer effects on Social Democrats than on members of the Center-Right block.

\subsection{Mechanisms and Deliberation Dynamics}

The results from Table 10 demonstrate that Vänsters and Swedish Democrats typically exert peer effects on nämndemän from centrist parties that are consistent with their respective party platforms. The goal of this section is to distinguish among potential explanations for these estimated peer effects and, more importantly, to determine whether these peer influences actually affect trial outcomes.

The previous literature in this area has drawn a distinction between two key mechanisms of peer influence. The first is a "sway effect" in which jurors actually impact peers' points of view, changing their evaluation of the case. Importantly, if the juror being swayed is the swing voter, then this form of peer influence can have real consequences for 
trial outcomes. The second mechanism is "dissent aversion" whereby jurors who would otherwise vote against the majority change their vote simply to make the decision unanimous. A nämndemän may wish to avoid dissent because of a potential negative collegial effect on the judge (who must write up a brief summary of the dissent) and the other nämndemän in the majority opinion, given that they may sit together again in future cases. ${ }^{40}$ In this way, while both sway effects and dissent aversion are consistent with the results presented in Tables 8-10, distinguishing between these mechanisms is important for determining whether peer effects actually impact trial outcomes or are purely incidental.

To provide additional evidence on these mechanisms, we first re-examine some of the results presented above and then conduct a two-part simulation exercise. Our re-examination of the results begins with the observation (seen in Appendix Table 3) that, among female victim cases, jurors from both Social Democrats and the Center-Right block have nearly identical own effects, implying they would vote similarly in the absence of peer effects. Thus, in the absence of a sway effect, the predicted effect of adding a Vänster to a case should only be determined by whether the Vänster swings the majority, which should be similar no matter which centrist party is their peer. Notice, however, that the results presented in column (1) of Table 7 imply a significantly larger impact of adding a Vänster to a female victim case in a juror triplet with a majority of soft-on-crime members (i.e. typically at least one member of the Social Democrat party) versus a majority of non-soft-on-crime members (i.e. typically two members from the Center-Right block). This suggests that Vänsters are swaying Social Democrats, pulling them towards their own position in a way that actually affects the verdict. This conclusion is also consistent with the way the parties line up in terms of platforms, as Vänsters often tend to politically align with Social Democrats. In contrast, the peer effects

\footnotetext{
${ }^{40}$ The idea of dissent aversion was put forth in studies of judge panel effects in federal courts of appeals (Epstein et al., 2011; Posner, 2008) where a dissent can impose a cost both on the dissenting judge (who writes up the dissenting opinion) and the judge that writes up the majority opinion (and must respond to the dissent). Subsequently, Fischman (2011) used a structural model to show that judicial voting patterns in federal appeals courts were consistent with judges having a cost of dissent.
} 
that Swedish Democrats exert on Social Democrats in Arabic-named defendant cases are more difficult to disentangle as these results are consistent with either a sway effect or dissent aversion. $^{41}$

\subsubsection{Simulation Part I: Predicting Trial Outcomes in the Absence of Peer Effects}

To examine the relative importance of sway effects and dissent aversion more directly, we conduct a two-part simulation exercise. The results presented in this section attempt to break down how much of the overall impact a Vänster or Swedish Democrat has on trial outcomes can be specifically attributed to their direct effect and how much can be attributed to peer effects (i.e. their ability to sway a pivotal voter).

The basic idea is to first simulate verdicts in a world without peer effects - i.e., one in which individual jurors make a decision in the absence of deliberating with anyone else and these votes are aggregated using a majority rule to determine a final verdict. Recreating Table 5 with these simulated verdicts should reveal the impact adding a Vänster or Swedish Democrat has on trial outcomes solely through their direct effect. And, because the results originally presented in Table 5 show the actual impact of adding these extreme party members (which include both their direct and sway effect), the difference between these actual and

\footnotetext{
${ }^{41}$ To see this, recall that the results from Table 7, Column 3 imply that, if anything, adding a Swedish Democrat to a majority soft panel has more of a positive impact on the conviction likelihood than adding a Swedish Democrat to a triplet with only one other soft member. This is consistent with Swedish Democrats swaying Social Democrats, as then we would expect the effect on trial outcomes to be greater when we increase the number of Social Democrats with whom Swedish Democrats sit. However this pattern of results is also consistent with Social Democrats simply engaging in dissent aversion once we take into account that Appendix Table 3 shows the Center-Right block is actually less likely than Social Democrats to convict Arabic-named defendants. If Social Democrats are simply avoiding dissent, then the impact of adding a Swedish Democrat on trial outcomes is only the latter's direct effect. Since Social Democrats are actually more likely than the CenterRight block to convict in these cases, Swedish Democrats will have a larger direct effect when they are seated with more of them; thus the impact of adding a Swedish Democrat would be expected to be larger when the majority of the panel is soft. We thus cannot determine whether Social Democrats are being swayed or averting dissent.
} 
simulated effects should reveal how much of their impact comes from their ability to sway pivotal voters. $^{42}$

The first step in the simulation procedure is to predict the likelihood that each nämndemän would vote to convict in the absence of peer effects. We identify this by estimating a specification similar to that in Appendix Table 2, which essentially regresses an individual nämndemän's vote on their own characteristics, case characteristics and peer fixed effects. ${ }^{43}$ With the exception of some gender and party balancing, individual nämndemän are randomly assigned to both cases and their peers. Since we control for the only source of nonrandomness through peer fixed effects, the coefficients should reveal the causal impact an individual's own characteristics have on their conviction likelihood. ${ }^{44,45}$ We then set the peer fixed effect coefficients to zero and compute the fitted values of this regression using only the effect of individual nämndemän attributes and defendant and case characteristics. This should identify the probability with which each nämndeman would vote to convict on the average case that has the same observables as the one they sat on, in the absence of peer effects. From this regression, we also estimate the residual for each nämndeman-defendant observation, calculate the mean residual across nämndemän in each case, and construct the empirical distribution of the means across cases. This distribution will be used in the simulation to allow correlated decision-making across nämndemän that sit on the same case.

We then merge these individual nämndeman predicted likelihoods into the case level data set used in the baseline analysis in Table 5. This results in 888 observations, as we

\footnotetext{
${ }^{42}$ Note that their ability to sway non-pivotal voters will not show up in these results since it would not have any effect on trial outcomes.

${ }^{43}$ The primary difference between this regression and the one presented in Appendix Table 3 is that we include interactions between each party and the case characteristics (female victims, Arabic defendants, and young defendants) to account for the differences across columns of Appendix Table 3.

${ }^{44}$ The results of our simulation exercises are completely robust to basing individual voting predictions on a specification that excludes peer fixed effects. That the individual vote predictions are not affected by conditioning on peer fixed effects implies any balancing issue does not affect the random assignment of peers to each other in an important way.

${ }^{45}$ The results of our simulation exercises are also completely robust to basing individual voting predictions on a specification that includes interactions between peer characteristics and own characteristics (such as own partypeer party interactions).
} 
exclude cases for which at least one of the three nämndemäns' votes could not be predicted because of missing information about the nämndeman's age or experience (see footnote 30 for additional details). We take a bootstrapped sample equal in size to the data set and simulate each nämndeman's vote by taking a draw from a binomial distribution where the probability of a guilty vote is determined by the sum of the individual nämndeman's own predicted probability plus a draw from the distribution of mean residuals across cases. ${ }^{46}$ This procedure allows for correlated decision-making that might naturally result because of the specific elements of a case, as the same draw from the mean residuals is applied to all three nämndemän on a simulated case. Finally, we add the simulated nämndemän votes with the actual vote of the judge and apply a majority rule to simulate the verdict in the case; a defendant is guilty if there are at least three guilty votes. We then estimate specifications comparable to those in columns (5) and (6) of Table 5; recall that these specifications regress whether there is at least one conviction on a dummy for each extreme party, case characteristics (female victim and Arabic defendants, respectively), and party*case interactions. ${ }^{47} \mathrm{We}$ repeat this exercise 500 times and present the mean of estimated coefficients and the associated standard errors in Table 11.

For comparison purposes, the odd columns of Table 11 present the results when using the actual verdict in the case, while the even columns present the results when the dependent variable is the simulated verdict. ${ }^{48}$ Column 1 shows that having a Vänster on a female victim case increases the likelihood of conviction by 14.2 percentage points; the simulation results in

\footnotetext{
${ }^{46}$ By including a draw from the distribution of mean residuals as part of individual voting behavior, we are implicitly assuming that any remaining correlation in voting (after peer fixed effects are excluded) is due to factors related to the case and not any form of unobserved peer effects. In this way, we are attempting to be as conservative as possible in estimating the role of peer effects on voting behavior. If we instead exclude this correlated error draw when predicting individual voting behavior, we estimate that sway peer effects are about twice as important (although the direct effect still makes up the majority of the overall impact of adding extreme nämndemän) and that unanimous decisions arise in even fewer cases.

${ }^{47}$ The results presented here include the full set of controls, as in Table 5. They are also robust to a more streamlined specification with no controls.

${ }^{48}$ Note that the estimates in Columns 1 and 3 differ slightly from those presented in Table 5 due to the modest change in the sample (described above) that resulted in 888 observations for the simulation exercises.
} 
Column 2 show this effect drops to 11.6 percentage points when peer effects are eliminated. ${ }^{49}$ This implies that roughly 18 percent of the overall effect Vänsters have on trial outcomes comes from their ability to sway pivotal peers. Similarly, Columns 3 and 4 show that the impact of adding a Swedish Democrat to an Arabic named defendant case declines from 23.0 to 21.7 percentage points when peer effects are eliminated; this implies that less than 6 percent of the overall effect Swedish Democrats have on trial outcomes is from their ability to sway pivotal peers.

These results are consistent with our above discussion of the results in Table 7, as both exercises suggest that at least some of the total effect of adding a Vänster is due to their ability to sway their peers. However, as the simulation results show, the majority of the effect of adding Vänsters and, especially, Swedish Democrats to a jury comes from the direct effect that they have on the decision as pivotal voters, rather than from peer effects. ${ }^{50}$

The first part of our simulation exercise also provides suggestive evidence of dissent aversion. For the 500 simulated bootstrap samples, the average share of cases with at least one dissent is about 20 percent. That is, if individual nämndemän votes were determined by their own characteristics and the characteristics of the case, as in our simulation, then about 80 percent of cases would result in a unanimous verdict. This sharply contrasts with the data. As reported in Table 2, just eight percent of cases have a dissenting opinion, and this includes dissents on both verdicts and sentences; just four percent of cases have a dissenting opinion on the verdict in the real world.

\subsubsection{Simulation Part II: Distinguishing Sway Effects from Dissent Aversion}

The much higher rate of non-unanimous decisions in the simulated sample (20 percent) versus the data (4 percent) naturally suggests a way to get a sense of how important dissent

\footnotetext{
${ }^{49}$ Note that these numbers are based on the sum of the any_vanster and any_vanster*any_femalevic coefficients.

${ }^{50}$ The same patterns hold when looking at the young defendant - party interactions.
} 
aversion might be in driving the peer effects estimated above. In particular, we can mimic dissent aversion in the simulations by switching dissenting votes in many of the nonunanimous cases in order to match the rate of unanimity observed in the data. We can then re-estimate comparable peer effects specifications to those presented above - e.g., in Table 8 in these simulated data to see whether dissent aversion alone is capable of explaining the estimated peer effects in the actual data.

It is important to point out from the outset that this second part of our simulation provides an upper bound for the importance of the dissent aversion mechanism and a lower bound for the importance of sway effects. In particular, this exercise assumes that all of the difference in the rate of unanimous decisions between the simulated and actual data is due to dissent aversion, when, in fact, sway effects would also naturally switch some split-vote cases to unanimous decisions - i.e., when a juror that would have been a lone dissenter changes their actual evaluation of the case due to sway effects.

The exact procedure that we use for the second part of the simulation is as follows: we randomly switch dissenting opinions in 80 percent of the non-unanimous simulated verdicts to make these unanimous, bringing unanimous decisions up to 96 percent in the simulated sample to match the data. We then transform the case level data set into an individual-level data set comparable to that used in the peer effects analysis and re-estimate the peer effect specifications in Table 8 .

Panel A of Table 12 presents the results when using the actual vote, while Panel B uses the simulated vote. ${ }^{51}$ Any peer effect that is observed in Panel B provides an upper bound on dissent aversion while the difference between the estimates in Panels A and B provides a lower bound on the share of the estimated peer effect that can be attributed to sway effects. The results presented in Table 12 indicate that at least one-third of the Vänster peer effect

\footnotetext{
${ }^{51}$ Note that the estimates using the actual vote are not identical to those in Table 8 because (i) we use the slightly reduced sample of 888 defendant-case observations here, and (ii) we use whether there are any convictions rather than at least one conviction as the dependent variable.
} 
across all three categories (female victims, Arabic defendants and young defendants) is driven by sway effects, which have real impacts on the verdicts. ${ }^{52}$ In contrast, virtually none of the Swedish Democrat peer effects are driven by sway effects.

\section{Conclusion}

That a defendant should receive a fair trial in which the verdict is decided only on the basis of the evidence is a fundamental principle of most criminal justice systems. But the challenge of designing and implementing a system that is capable of achieving this abstract goal is immediately obvious as soon as one confronts the practical questions of how jurors should be assigned, especially in settings where members of the local population may have biases for or against certain kinds of defendants.

Faced with this challenge, many justice systems use a selection process that attempts to form juries that are somehow representative of the local population or public opinion. In the United States, a 'representative' jury is typically determined by a random draw from a list of eligible jurors from the local community. But recent empirical studies, as well as a long history of anecdotal evidence, have raised serious concerns about biases in this system, particularly when minority members of the local population (where minority could be defined in any number of dimensions including race, ethnicity, and religion) face juries that are representative and, therefore, include few, if any, members of the minority group.

Sweden's nämndemän system provides an alternative approach to selecting jurors that are representative of the local population. In the nämndemän system, the share of lay judges from each political party is proportionate to how the local population voted in the last election, thereby achieving representativeness in the sense of the locality's political

\footnotetext{
${ }^{52}$ If we are even more conservative in the second part of the simulation, and turn 100 percent of the nonunanimous votes to unanimous, we still find that at least 20 percent of the Vänster peer effect is attributable to a sway effect.
} 
ideologies. ${ }^{53}$ Given the lack of existing empirical evidence on jury verdicts outside of the United States, our paper provides an opportunity to assess whether the Swedish system is capable of delivering a 'fair' trial - does the presence (and vote) of the professional judge and the fact that the lay judges are politically appointed to office rather than randomly drawn from the population lead to impartiality?

Our findings imply that significant biases exist in the Swedish system; biases that are, in fact, closely associated with positions of the nämndeman's political party. For instance, having a far-left Vänster or far-right Swedish Democrat in the nämndeman triplet assigned to a case significantly impacts the likelihood of conviction in cases closely related to the party's platform - female victims (feminism) and Arabic named defendants (anti-immigration), respectively. The latter finding may be particularly relevant outside of Sweden, given the rise of far right parties throughout Europe similar in platform to the Swedish Democrats.

Importantly, the political affiliations of the nämndemän assigned to a case affected the actual verdicts in the case and were not just reflected in dissenting opinions. Thus, contrary to some opinions in Sweden and around the world, nämndemän (and lay judges more generally) are not inconsequential, even when deliberating in collaboration with a professional judge. This implies that proposals to reduce the role of nämndemän (or eliminate them from some cases) would have a real impact on verdicts.

Alternative appointment processes that aim to de-emphasize the role of politics have also been suggested. In particular, the most recent government proposal to change the nämndemän system included suggestions to: (i) not appoint nämndemän in direct connection with elections and (ii) investigate how to introduce a share of nämndemän who would be

\footnotetext{
${ }^{53}$ There are, of course, other key differences between the U.S. and Swedish systems. American verdicts are unanimous while a majority is required in Sweden and verdicts are decided by American juries without the presence of the professional judge, while Swedish verdicts are decided by a professional judge in collaboration with three lay judges.
} 
chosen outside the political parties. ${ }^{54}$ Whether these measures would reduce biases in the nämndemän system associated with political ideology depends, of course, on whether the nämndemän that would be appointed through this process would be materially different than those that serve in the current system.

The selection of jurors is, of course, only one aspect of the design of jury systems and other dimensions (including the size of the jury, the voting rules, and the requirements for conviction) impact the collective decisions reached by groups of jurors. In fact, we know very little about how jurors decide verdicts collectively in real trial settings. By exploiting variation in the assignment of jurors not only to cases but to one another, our analysis also contributes to the nascent literature on the dynamics of jury deliberations. Our simulation exercises find that the vast majority of the effect of adding Vänsters and, especially, Swedish Democrats comes from the direct effect of them being pivotal voters rather than from their influence on their peers. Though virtually all of the Swedish Democrat peer effects operate through dissent aversion, such that the influence of the Swedish Democrat nämndeman on his peers does not influence verdicts, we find that at least one-third of the Vänster peer effect is due to sway effects, where a Vänster nämndeman convinces a fellow juror of their standpoint. These results provide the first empirical evidence in the literature based on actual trials on the ways that jurors influence one another during group decision-making. The nature of these peer effects imply that, in some cases, groups of jurors do more than simply aggregate (or average) opinions and that jury deliberation and decision-making processes can indeed have systematic effects on verdicts.

\section{References}

Abrams, David, Marianne Bertrand, and Sendhil Mullainathan (2012) "Do Judges Vary in Their Treatment of Race?" Journal of Legal Studies, 41(2): 347-383.

\footnotetext{
${ }^{54} \mathrm{http}: / /$ www.regeringen.se/sb/d/18449/a/233942
} 
Anwar, Shamena, Patrick Bayer and Randi Hjalmarsson (2012) "The Impact of Jury Race in Criminal Trials" Quarterly Journal of Economics, 127(2), 1017-1055.

Anwar, Shamena, Patrick Bayer and Randi Hjalmarsson (2014) "The Role of Age in Jury Selection and Trial Outcomes", Journal of Law and Economics, 57(4), 1001-1030.

Ashenfelter, Orley, Theodore Eisenberg, and Steward J. Schwab (1995) "Politics and the judiciary: The Influence of Judicial Background on Case Outcomes" The Journal of Legal Studies, 24(2): $257-281$.

Blanes I Vidal, Jordi and Clare Leaver (2013) "Social Interactions and the Content of Legal Opinions" Journal of Law, Economics, and Organization, 29: 78-114.

Boyd, Christina, Lee Epstein and Andrew Martin (2010) "Untangling the Causal Effects of Sex on Judging" American Journal of Political Science, 54(2): 389-411.

Brå (2012), "Brottslighet och trygghet I Malmö, Stockholm och Göteborg”, URN:NBN:SE:BRA-473

Casper, Gerhard and Hans Zeisel (1972) "Lay Judges in the German Criminal Courts" The Journal of Legal Studies, 1: 135-191.

Clark, J, M. Boccaccini, B. Caillouet, and W. Chaplin (2007), "Five Factor Model Personality Traits, Jury Selection, and Case Outcomes in Criminal and Civil Cases" Criminal Justice and Behavior, 34: 641-660.

Cross, Frank and Emerson Tiller (1998) "Judicial Partisanship and Obedience to Legal Doctrine: Whistleblowing on the Federal Courts of Appeals" Yale Law Journal 107: 21552176.

Devine, Dennis (2012) Jury Decision Making: The State of the Science, New York University Press.

Devine, Dennis, Laura Clayton, Benjamin Dunford, Rasmy Seying, and Jennifer Pryce (2000). "Jury Decision Making: 45 Years of Empirical Research on Deliberating Groups". Psychology, Public Policy, and Law, 7:3, 622-727.

Diamon, Shari and Mary Rose (2005) "Real Juries" Annual Review of Law and Social Science, 1: 255-284.

Domstolverket (2010), Regeringens mål: Fler yngre nämndemän, http://www.domstol.se/templates/DV_Press.aspx?id=18997

Epstein, Lee, William Landes and Richard Posner (2011) "Why (and When) Judges Dissent: A Theoretical and Empirical Analysis" Journal of Legal Analysis 3, 101-137.

Fischman, Joshua (2011) "Estimating Preferences of Circuit Judges: A Model of Consensus Voting" Journal of Law and Economics 54(4): 781-809.

Fischman, Joshua (2013) "Interpreting Circuit Court Voting Patterns: A Social Interactions Framework" Journal of Law, Economics, and Organization. 
Gazal-Ayal, Oren and Raanan Sulitzeanu-Kenan (2010) "Let My People Go: Ethnic In-Group Bias in Judicial Decisions - Evidence from a Randomized Natural Experiment" Journal of Empirical Legal Studies, 7(3): 403-428.

Hans, Valerie (2008) "Jury Systems Around the World" Cornell Law Faculty Publications. Paper 305.

Hans, Valerie and Nicole Waters (2009) "A Jury of One: Opinion Formation, Conformity, and Dissent on Juries" Journal of Empirical Legal Studies, 6.

Holmberg, Sören and Oscarsson, Henrik. SWEDISH NATIONAL ELECTION STUDY 2010 [data file]. Department of Political Science, 2012. Gothenburg, Sweden: Swedish National Data Service (SND) [distributor].

Iaryczower, Matias and Matthew Shum (2012) "The Value of Information in the Court: Get Right, Keep it Tight," American Economic Review, 102(1): 202-237.

Jackson, John and Nikolay Kovalev (2006) "Lay Adjudication and Human Rights in Europe", Colum. L. Rev. 83.

Lee, Jean N. (2014) "The Process is the Punishment: Juror Demographics and Case Administration in State Courts", Mimeo.

Lehmann, Jee-Yeon K. and Jeremy Blair Smith (2013) "A Multidimensional Examination of Jury Composition, Trial Outcomes, and Attorney Preferences", Mimeo.

Lim, Claire, James Snyder, and David Strömberg (forthcoming) "The Judge, The Politician and The Press: Newspaper Coverage and Criminal Sentencing across Electoral Systems", American Economic Journal: Applied Economics.

MacCoun, Robert (1989) "Experimental Research on Jury Decision-Making” Science 244: 1046-1050.

Marcus, D, P Lyons, and M Guyton (2000) "Studying Perceptions of Juror Influence in Vivo: A Social Relations Analysis" Law and Human Behavior, 24: 173-186.

Marten, Linna (2015) "Political Bias in Court? Lay Judges and Assylum Appeals", Working Paper.

Miles, Thomas (2012) "The Law's Delay: A Test of The Mechanisms of Judicial Peer Effects" Journal of Legal Analysis 4.

Miles, Thomas J. and Cass R. Sunstein. 2006. "Do Judges Make Regulatory Policy? An Empirical Investigation of Chevron," 73 University of Chicago Law Review 823-82

Mills, Carol and Wayne Bohannon (1980). "Jury Characteristics: To What Extent Are They Related to Jury Verdicts?” Judicature, 64, 22.

Posner, Richard (2008) How Judges Think. Cambridge, MA: Harvard University Press.

Revesz, Richard L. 1997. "Environmental Regulation, Ideology, and the D.C. Circuit," 83 Virginia Law Review 1717-72. 
Shayo, Moses and Asaf Zussman (2011) "Judicial Ingroup Bias in the Shadow of Terrorism", The Quarterly Journal of Economics, 126 (3): 1447-1484.

Schanzenbach, Max and Emerson Tiller (2008) "Reviewing the Sentencing Guidelines: Judicial Politics, Empirical Evidence, and Reform," University of Chicago Law Review, 75: 715.

SOM Institute. NATIONAL SOM 2010 [data file]. SOM Institute, 2011. Gothenburg, Sweden: Swedish National Data Service (SND) [distributor].

Spitzer, Matthew and Eric Talley (2013) "Left, Right, and Center: Strategic Information Acquisition and Diversity in Judicial Panels" Journal of Law, Economics and Organization

Schkade, David, Cass Sunstein, and Reid Hastie (2007) "What Happened on Deliberation Day?" California Law Review 95.

Sunstein, Cass R., David Schkade, Lisa M. Ellman, and Andres Sawicki. 2006. Are Judges Political?: An Empirical Analysis of the Federal Judiciary, Washington: Brookings Institution Press.

Tuerkheimer, Alan, (2008) “Politics in Civil Jury Selection”, Wisconsin Lawyer, 81(12).

York, E. and B. Cornwell (2006) "Status on Trial: Social Characteristics and Influence in the Jury Room” Social Forces, 85: 455-477. 
Table 1. Survey Evidence of Party Beliefs

\begin{tabular}{|c|c|c|c|c|c|c|c|c|}
\hline & \multicolumn{4}{|c|}{ VU 2010 Election Survey Analysis } & \multicolumn{4}{|c|}{ RIKS SOM 2010 Survey Analysis } \\
\hline & (1) & $(2)$ & $(3)$ & $(4)$ & $(5)$ & $(6)$ & $(7)$ & $(8)$ \\
\hline & $\begin{array}{c}\text { Favor or } \\
\text { Strongly Favor } \\
\text { Harsher Prison } \\
\text { Sentences } \\
\end{array}$ & $\begin{array}{c}\text { Favor Working } \\
\text { to a Society with } \\
\text { More Law and } \\
\text { Order }\end{array}$ & $\begin{array}{c}\text { Against or } \\
\text { Strongly Against } \\
\text { Harsher Prison } \\
\text { Sentences } \\
\end{array}$ & $\begin{array}{l}\text { Strongly } \\
\text { Support } \\
\text { Gender } \\
\text { Equality } \\
\end{array}$ & $\begin{array}{l}\text { Courts Give } \\
\text { Unreasonable } \\
\text { Punishments } \\
\end{array}$ & $\begin{array}{c}\text { Immigrants are } \\
\text { Punished } \\
\text { Harhser } \\
\end{array}$ & $\begin{array}{c}\text { Immigrants are } \\
\text { Not Punished } \\
\text { Harsher } \\
\end{array}$ & $\begin{array}{l}\text { Strongly Suppor } \\
\text { Gender Equality }\end{array}$ \\
\hline Vänster (left) & $\begin{array}{l}-0.150 * * \\
(0.0610)\end{array}$ & $\begin{array}{l}-0.126^{* *} \\
(0.0593)\end{array}$ & $\begin{array}{l}0.158 * * * \\
(0.0523)\end{array}$ & $\begin{array}{c}0.172 * * * \\
(0.0607)\end{array}$ & $\begin{array}{l}-0.00833 \\
(0.0396)\end{array}$ & $\begin{array}{c}0.126 * * * \\
(0.0323)\end{array}$ & $\begin{array}{l}-0.0548 \\
(0.0383)\end{array}$ & $\begin{array}{c}0.150 * * * \\
(0.0352)\end{array}$ \\
\hline Green & $\begin{array}{c}-0.186^{* * *} \\
(0.0505)\end{array}$ & $\begin{array}{c}-0.138 * * * \\
(0.0490)\end{array}$ & $\begin{array}{c}0.167 * * * \\
(0.0433)\end{array}$ & $\begin{array}{l}0.114^{* *} \\
(0.0505)\end{array}$ & $\begin{array}{l}0.0629 * \\
(0.0360)\end{array}$ & $\begin{array}{c}0.0302 \\
(0.0308)\end{array}$ & $\begin{array}{l}-0.0446 \\
(0.0365)\end{array}$ & $\begin{array}{c}0.144 * * * \\
(0.0300)\end{array}$ \\
\hline Center & $\begin{array}{l}-0.133 * * \\
(0.0556)\end{array}$ & $\begin{array}{c}0.0368 \\
(0.0536)\end{array}$ & $\begin{array}{c}0.0285 \\
(0.0477)\end{array}$ & $\begin{array}{c}0.0223 \\
(0.0552)\end{array}$ & $\begin{array}{l}-0.0576 \\
(0.0376)\end{array}$ & $\begin{array}{c}0.0126 \\
(0.0329)\end{array}$ & $\begin{array}{l}-0.00855 \\
(0.0390)\end{array}$ & $\begin{array}{c}-0.0910 * * * \\
(0.0324)\end{array}$ \\
\hline Folk & $\begin{array}{c}0.0260 \\
(0.0527)\end{array}$ & $\begin{array}{c}0.174 * * * \\
(0.0509)\end{array}$ & $\begin{array}{l}-0.0487 \\
(0.0452)\end{array}$ & $\begin{array}{l}0.00655 \\
(0.0526)\end{array}$ & $\begin{array}{c}0.0238 \\
(0.0338)\end{array}$ & $\begin{array}{c}-0.0670 * * \\
(0.0288)\end{array}$ & $\begin{array}{c}0.0157 \\
(0.0342)\end{array}$ & $\begin{array}{c}-0.0656^{* *} \\
(0.0304)\end{array}$ \\
\hline Christian Democrat & $\begin{array}{c}0.0326 \\
(0.0601)\end{array}$ & $\begin{array}{l}0.266 * * * \\
(0.0581)\end{array}$ & $\begin{array}{l}-0.0573 \\
(0.0516)\end{array}$ & $\begin{array}{c}-0.172 * * * \\
(0.0599)\end{array}$ & $\begin{array}{l}-0.0557 \\
(0.0380)\end{array}$ & $\begin{array}{c}-0.0685 * * \\
(0.0333)\end{array}$ & $\begin{array}{c}0.0507 \\
(0.0395)\end{array}$ & $\begin{array}{c}-0.120 * * * \\
(0.0334)\end{array}$ \\
\hline Moderates & $\begin{array}{c}0.0922 * * * \\
(0.0351)\end{array}$ & $\begin{array}{c}0.174 * * * \\
(0.0341)\end{array}$ & $\begin{array}{c}-0.0964 * * * \\
(0.0302)\end{array}$ & $\begin{array}{l}-0.0400 \\
(0.0351)\end{array}$ & $\begin{array}{c}0.0316 \\
(0.0218)\end{array}$ & $\begin{array}{c}-0.0576^{* * *} \\
(0.0188)\end{array}$ & $\begin{array}{l}0.0398 * \\
(0.0223)\end{array}$ & $\begin{array}{c}-0.0853 * * * \\
(0.0187)\end{array}$ \\
\hline Swedish Democrats & $\begin{array}{c}0.239 * * * \\
(0.0772)\end{array}$ & $\begin{array}{c}0.278 * * * \\
(0.0751)\end{array}$ & $\begin{array}{l}-0.0986 \\
(0.0662)\end{array}$ & $\begin{array}{l}-0.131^{*} \\
(0.0774)\end{array}$ & $\begin{array}{c}0.256^{* * * *} \\
(0.0444)\end{array}$ & $\begin{array}{l}-0.0694 * \\
(0.0361)\end{array}$ & $\begin{array}{c}0.305 * * * \\
(0.0428)\end{array}$ & $\begin{array}{l}-0.0363 \\
(0.0408)\end{array}$ \\
\hline _cons & $\begin{array}{c}0.764 * * * \\
(0.103) \\
\end{array}$ & $\begin{array}{c}0.619 * * * \\
(0.100) \\
\end{array}$ & $\begin{array}{c}0.109 \\
(0.0885) \\
\end{array}$ & $\begin{array}{c}0.430 * * * \\
(0.103) \\
\end{array}$ & $\begin{array}{l}0.412 * * * \\
(0.0392) \\
\end{array}$ & $\begin{array}{c}0.157 * * * \\
(0.0331) \\
\end{array}$ & $\begin{array}{c}0.245 * * * \\
(0.0392) \\
\end{array}$ & $\begin{array}{c}0.483 * * * \\
(0.0335) \\
\end{array}$ \\
\hline $\mathrm{N}$ & 1209 & 1218 & 1209 & 1221 & 2360 & 1877 & 1877 & 4556 \\
\hline R-sq & 0.173 & 0.128 & 0.143 & 0.048 & 0.047 & 0.028 & 0.042 & 0.056 \\
\hline
\end{tabular}

Standard errors in parentheses. $*$ is significant at $10 \%, * *$ at $5 \%$ and $* * *$ at $1 \%$. The dependent variable in each specification is listed at the top of the column. All specifications control for age, gender, citizenship, education, and whether respondents live in an urban area. Note that the omitted category is social democrats. Also, note that adding the controls had little impact on the magnitude of the baseline estimates. In addition, controlling for left/right ideology generally has little impact. 
Table 2. Summary Statistics for Case by Defendant Level Data

\begin{tabular}{|c|c|c|c|}
\hline Variable & Obs & Mean & Std. Dev. \\
\hline \multicolumn{4}{|l|}{ Nämndemän Triplet Characteristics } \\
\hline any social democrats? & 1129 & 0.74 & 0.44 \\
\hline any vänster (left)? & 1129 & 0.20 & 0.40 \\
\hline any miljö (green)? & 1129 & 0.27 & 0.44 \\
\hline any christian democrats? & 1129 & 0.13 & 0.33 \\
\hline any moderates? & 1129 & 0.69 & 0.46 \\
\hline any folk party? & 1129 & 0.29 & 0.45 \\
\hline any center party? & 1129 & 0.02 & 0.15 \\
\hline any swedish democrats? & 1129 & 0.09 & 0.29 \\
\hline any local party (vägvalet)? & 1129 & 0.10 & 0.30 \\
\hline majority nämndemän male? & 1152 & 0.46 & 0.50 \\
\hline any nämn. with nonswedish name? & 1147 & 0.40 & 0.49 \\
\hline average age of triplet & 1151 & 58.06 & 9.01 \\
\hline average age $>=50$ & 1151 & 0.83 & 0.38 \\
\hline average experience $2-4$ years? & 1150 & 0.36 & 0.48 \\
\hline average experience $4-6$ years? & 1150 & 0.24 & 0.43 \\
\hline average experience $>6$ years? & 1150 & 0.23 & 0.42 \\
\hline \multicolumn{4}{|l|}{ Defendant Characteristics } \\
\hline defendant age & 1143 & 32.20 & 14.06 \\
\hline defendant male & 1137 & 0.91 & 0.28 \\
\hline defendnat non swedish citizen & 1152 & 0.12 & 0.32 \\
\hline defendant has arabic name & 1152 & 0.22 & 0.42 \\
\hline any_past convictions? & 1144 & 0.36 & 0.48 \\
\hline any violent past convictions? & 1144 & 0.20 & 0.40 \\
\hline \multicolumn{4}{|l|}{ Case Characteristics } \\
\hline \# offenses & 1143 & 1.87 & 1.47 \\
\hline any_robbery & 1144 & 0.05 & 0.22 \\
\hline any_rape (child/adult) & 1144 & 0.08 & 0.28 \\
\hline any_assault & 1144 & 0.56 & 0.50 \\
\hline any_aggravated assault & 1144 & 0.13 & 0.34 \\
\hline any_unlawful threat & 1144 & 0.26 & 0.44 \\
\hline any manslaughter/murder & 1144 & 0.03 & 0.17 \\
\hline any drunk drive & 1144 & 0.02 & 0.14 \\
\hline any_drugs & 1144 & 0.11 & 0.31 \\
\hline any_other_sex_off & 1144 & 0.07 & 0.26 \\
\hline any_other & 1144 & 0.28 & 0.45 \\
\hline \# victims & 1148 & 1.51 & 1.22 \\
\hline any female victims? & 1129 & 0.50 & 0.50 \\
\hline \# defendants & 1151 & 1.69 & 1.62 \\
\hline full admission of guilt? & 1124 & 0.09 & 0.29 \\
\hline partial admission of guilt? & 1124 & 0.46 & 0.50 \\
\hline \multicolumn{4}{|l|}{ Case Outcomes } \\
\hline any current convictions? & 1152 & 0.88 & 0.33 \\
\hline share of current offenses convicted & 1142 & 0.83 & 0.34 \\
\hline any_prison? & 1008 & 0.30 & 0.46 \\
\hline any dissenting opinions? & 1152 & 0.08 & 0.27 \\
\hline dissenting opinion up? & 1152 & 0.05 & 0.21 \\
\hline dissenting opinion down? & 1152 & 0.03 & 0.18 \\
\hline \multicolumn{4}{|l|}{ Judge Variables } \\
\hline judge_age & 1107 & 49.99 & 9.67 \\
\hline judge male & 1152 & 0.55 & 0.50 \\
\hline
\end{tabular}


Table 3. Random Assignment of Nämndemän Triplets and Judges

\begin{tabular}{|c|c|c|c|c|c|c|c|c|c|c|c|c|}
\hline & $\begin{array}{c}\text { (1) } \\
\text { any__ } \\
\text { vänster }\end{array}$ & $\begin{array}{l}\text { (2) } \\
\text { any__ } \\
\text { green }\end{array}$ & $\begin{array}{l}(3) \\
\text { any_ } \\
\text { krist } \\
\text { dem }\end{array}$ & $\begin{array}{l}\text { (4) } \\
\text { any_- } \\
\text { folk }\end{array}$ & $\begin{array}{c}(5) \\
\text { any_ } \\
\text { swede } \\
\text { dem }\end{array}$ & $\begin{array}{c}\text { (6) } \\
\text { any_-_ } \\
\text { vägvalet }\end{array}$ & $\begin{array}{c}\text { (7) } \\
\text { maj_- } \\
\text { nämn_- } \\
\text { male }\end{array}$ & $\begin{array}{c}(8) \\
\text { any_ } \\
\text { non } \\
\text { swedish }\end{array}$ & $\begin{array}{c}\text { (9) } \\
\text { triplet_- } \\
\text { average } \\
\text { age }\end{array}$ & $\begin{array}{c}(10) \\
\text { triplet_- } \\
\text { average } \\
\text { exp }\end{array}$ & $\begin{array}{c}\text { (11) } \\
\text { judge_- } \\
\text { male }\end{array}$ & $\begin{array}{c}\text { (12) } \\
\text { judge_- } \\
\text { age }\end{array}$ \\
\hline \multicolumn{13}{|c|}{ F-test (p-value) of joint significance of: } \\
\hline $\begin{array}{l}\text { defendant characteristics } \\
\text { (4 variables) }\end{array}$ & $\begin{array}{c}0.89 \\
(0.47)\end{array}$ & $\begin{array}{c}0.77 \\
(0.54)\end{array}$ & $\begin{array}{c}0.68 \\
(0.61)\end{array}$ & $\begin{array}{c}0.19 \\
(0.95)\end{array}$ & $\begin{array}{c}0.71 \\
(0.58)\end{array}$ & $\begin{array}{c}1.23 \\
(0.30)\end{array}$ & $\begin{array}{c}0.47 \\
(0.76)\end{array}$ & $\begin{array}{c}1.05 \\
(0.38)\end{array}$ & $\begin{array}{c}0.81 \\
(0.52)\end{array}$ & $\begin{array}{l}1.44 \\
(0.22)\end{array}$ & $\begin{array}{c}2.01 \\
(0.09)\end{array}$ & $\begin{array}{c}2.24 \\
(0.06)\end{array}$ \\
\hline $\begin{array}{l}\text { offense characteristics } \\
\text { (11 variables) }\end{array}$ & $\begin{array}{c}0.81 \\
(0.63)\end{array}$ & $\begin{array}{l}1.46 \\
(0.14)\end{array}$ & $\begin{array}{c}3.36 \\
(0.00)\end{array}$ & $\begin{array}{c}1.21 \\
(0.28)\end{array}$ & $\begin{array}{c}1.07 \\
(0.38)\end{array}$ & $\begin{array}{l}1.46 \\
(0.14)\end{array}$ & $\begin{array}{c}0.75 \\
(0.69)\end{array}$ & $\begin{array}{l}1.21 \\
(0.27)\end{array}$ & $\begin{array}{c}0.72 \\
(0.72)\end{array}$ & $\begin{array}{l}1.75 \\
(0.06)\end{array}$ & $\begin{array}{c}1.85 \\
(0.04)\end{array}$ & $\begin{array}{c}0.50 \\
(0.90)\end{array}$ \\
\hline $\begin{array}{l}\text { case characteristics } \\
\text { ( } 5 \text { variables) }\end{array}$ & $\begin{array}{l}0.95 \\
(0.45)\end{array}$ & $\begin{array}{c}0.81 \\
(0.54)\end{array}$ & $\begin{array}{c}0.77 \\
(0.57)\end{array}$ & $\begin{array}{c}0.35 \\
(0.88)\end{array}$ & $\begin{array}{c}3.31 \\
(0.01)\end{array}$ & $\begin{array}{c}0.38 \\
(0.87)\end{array}$ & $\begin{array}{c}1.04 \\
(0.40)\end{array}$ & $\begin{array}{c}0.34 \\
(0.89)\end{array}$ & $\begin{array}{c}1.41 \\
(0.22)\end{array}$ & $\begin{array}{l}1.24 \\
(0.29)\end{array}$ & $\begin{array}{c}1.64 \\
(0.15)\end{array}$ & $\begin{array}{c}0.67 \\
(0.65)\end{array}$ \\
\hline $\begin{array}{l}\text { criminal history characteristics } \\
\text { ( } 2 \text { variables) }\end{array}$ & $\begin{array}{l}0.17 \\
(0.84)\end{array}$ & $\begin{array}{c}1.98 \\
(0.14)\end{array}$ & $\begin{array}{c}0.84 \\
(0.43)\end{array}$ & $\begin{array}{c}0.00 \\
(1.00)\end{array}$ & $\begin{array}{l}1.20 \\
(0.30)\end{array}$ & $\begin{array}{l}1.40 \\
(0.25)\end{array}$ & $\begin{array}{c}0.37 \\
(0.69)\end{array}$ & $\begin{array}{c}0.69 \\
(0.50)\end{array}$ & $\begin{array}{c}0.25 \\
(0.78)\end{array}$ & $\begin{array}{c}0.48 \\
(0.62)\end{array}$ & $\begin{array}{c}3.77 \\
(0.02)\end{array}$ & $\begin{array}{c}1.19 \\
(0.30)\end{array}$ \\
\hline $\begin{array}{l}\text { nämndemän political affiliations } \\
\text { ( } 7 \text { variables) }\end{array}$ & & & & & & & & & & & $\begin{array}{c}0.67 \\
(0.70)\end{array}$ & $\begin{array}{c}0.79 \\
(0.60)\end{array}$ \\
\hline $\begin{array}{l}\text { other nämndemän characteristics } \\
\text { ( } 5 \text { variables) }\end{array}$ & & & & & & & & & & & $\begin{array}{c}0.89 \\
(0.49)\end{array}$ & $\begin{array}{c}1.75 \\
(0.12)\end{array}$ \\
\hline \# coef significant at $5 \%$ level & 0 & 2 & 1 & 1 & 1 & 2 & 0 & 0 & 1 & 4 & 4 & 0 \\
\hline $\mathrm{N}$ & 1051 & 1051 & 1051 & 1051 & 1051 & 1051 & 1074 & 1069 & 1074 & 1073 & 1051 & 1011 \\
\hline R-sq & 0.025 & 0.022 & 0.021 & 0.016 & 0.028 & 0.034 & 0.023 & 0.023 & 0.030 & 0.037 & 0.072 & 0.043 \\
\hline
\end{tabular}

Each column presents the results of a regression of a nämndemän triplet or judge characteristics (listed at the top of the column) and a large set of controls that can are
grouped into six categories: defendant characteristics, offense characteristics, case characteristics, criminal history, nämndemän political affiliations, and other nämndemän characteristics. The results of these regressions are summarized in the above table by presenting the F-tests of the joint significance of the variables included in these categories. The table also reports the number of significant coefficients and the R-squared for each regression. F-tests are based on robust standard errors, clustered by case. 


\begin{tabular}{|c|c|c|c|c|}
\hline & \multicolumn{2}{|c|}{$\begin{array}{c}\text { Share of Current Offenses } \\
\text { Convicted }\end{array}$} & \multicolumn{2}{|c|}{ Any current convictions? } \\
\hline any_vänster & $\begin{array}{c}0.0584 \\
(0.0381)\end{array}$ & $\begin{array}{c}0.146^{*} \\
(0.0753)\end{array}$ & $\begin{array}{c}0.0572 \\
(0.0373)\end{array}$ & $\begin{array}{c}0.139^{*} \\
(0.0776)\end{array}$ \\
\hline any_green & $\begin{array}{c}0.0255 \\
(0.0322)\end{array}$ & $\begin{array}{c}0.0811 \\
(0.0607)\end{array}$ & $\begin{array}{l}-0.00227 \\
(0.0268)\end{array}$ & $\begin{array}{c}0.0469 \\
(0.0587)\end{array}$ \\
\hline any_swededem & $\begin{array}{l}-0.0377 \\
(0.0525)\end{array}$ & $\begin{array}{l}-0.00466 \\
(0.0968)\end{array}$ & $\begin{array}{l}-0.00865 \\
(0.0497)\end{array}$ & $\begin{array}{l}-0.00361 \\
(0.0959)\end{array}$ \\
\hline _cons & $\begin{array}{l}0.927 * * * \\
(0.0848)\end{array}$ & $\begin{array}{c}0.737 * * * \\
(0.193)\end{array}$ & $\begin{array}{l}0.826^{* * *} \\
(0.0837)\end{array}$ & $\begin{array}{l}0.711^{* * *} \\
(0.181)\end{array}$ \\
\hline Other Nämndemän Controls & Yes & Yes & Yes & Yes \\
\hline Judge Fixed Effects & Yes & Yes & Yes & Yes \\
\hline Def/Offense/Case Controls & Yes & Yes & Yes & Yes \\
\hline Sample & Full Admit $=0$ & No Admit $=1$ & Full Admit $=0$ & No Admit $=1$ \\
\hline $\mathrm{N}$ & 961 & 466 & 962 & 466 \\
\hline R-sq & 0.212 & 0.261 & 0.230 & 0.253 \\
\hline
\end{tabular}

Each column corresponds to a regression of the conviction outcome (denoted at the top of the column) on a dummy variable indicating the presence of each of three main extreme parties of interest, and include controls for other nämndemän characteristics (such as age, gender, non-swedish, and experience), defendant characteristics, offense characteristics and other case characteristics. Columns (1) and (3) use the full sample of cases that did not fully admit their guilt, while columns (2) and (4) focus on those cases that completely deny their guilt. Robust standard errors, clustered on judge name, are in parentheses. ${ }^{*} \mathrm{p}<0.10, * * \mathrm{p}<0.05, * * * \mathrm{p}<0.01$. 
Table 5. Baseline Party Platform*Case Characteristic Results

\begin{tabular}{|c|c|c|c|c|c|c|c|}
\hline & (1) & (2) & (3) & (4) & (5) & (6) & (7) \\
\hline & \multicolumn{4}{|c|}{ Share of Current Offenses Convicted } & \multicolumn{3}{|c|}{ Any Current Convictions? } \\
\hline \multirow[t]{2}{*}{ any_vänster } & -0.0126 & 0.0595 & 0.0357 & $0.108 * *$ & -0.0115 & $0.0637 *$ & $0.0924 * *$ \\
\hline & $(0.0520)$ & $(0.0377)$ & $(0.0557)$ & $(0.0424)$ & $(0.0475)$ & $(0.0354)$ & $(0.0432)$ \\
\hline \multirow[t]{2}{*}{ any_swededem } & -0.0702 & -0.0866 & -0.0921 & -0.0788 & 0.00134 & -0.0553 & -0.0392 \\
\hline & $(0.0760)$ & $(0.0586)$ & $(0.0703)$ & $(0.0568)$ & $(0.0625)$ & $(0.0568)$ & $(0.0550)$ \\
\hline \multirow[t]{2}{*}{ any_vänster*any_femalevic } & $0.148 * * *$ & & & & $0.143 * * *$ & & \\
\hline & $(0.0558)$ & & & & $(0.0527)$ & & \\
\hline \multirow[t]{2}{*}{ any_swedem*any_femalevic } & 0.0637 & & & & -0.0163 & & \\
\hline & $(0.0958)$ & & & & $(0.0783)$ & & \\
\hline \multirow[t]{2}{*}{ any_vänster*def_arabic name } & & -0.0115 & 0.00728 & & & -0.0276 & \\
\hline & & $(0.0661)$ & $(0.0790)$ & & & $(0.0597)$ & \\
\hline \multirow[t]{2}{*}{ any_swedem*def_arabic name } & & $0.260 * *$ & $0.283 * * *$ & & & $0.255^{* * *}$ & \\
\hline & & $(0.100)$ & $(0.101)$ & & & $(0.0851)$ & \\
\hline \multirow[t]{2}{*}{ any_vänster*def<21 } & & & & $-0.153 * *$ & & & $-0.105^{*}$ \\
\hline & & & & $(0.0622)$ & & & $(0.0606)$ \\
\hline \multirow[t]{2}{*}{ any_swedem*def<21 } & & & & $0.239 * * *$ & & & $0.169 * *$ \\
\hline & & & & $(0.0764)$ & & & $(0.0810)$ \\
\hline \multirow[t]{2}{*}{ def_arabic_name } & -0.00483 & -0.0236 & -0.0587 & -0.00146 & 0.00393 & 0.00270 & 0.00912 \\
\hline & $(0.0327)$ & $(0.0374)$ & $(0.0478)$ & $(0.0312)$ & $(0.0334)$ & $(0.0370)$ & $(0.0321)$ \\
\hline \multirow[t]{2}{*}{ any_female_vic } & -0.0218 & 0.00252 & 0.0167 & 0.00295 & -0.00903 & 0.00421 & 0.00466 \\
\hline & $(0.0390)$ & $(0.0320)$ & $(0.0385)$ & $(0.0310)$ & $(0.0398)$ & $(0.0325)$ & $(0.0314)$ \\
\hline \multirow[t]{2}{*}{$\operatorname{def}<21$} & -0.0268 & -0.0235 & -0.0109 & -0.0303 & -0.0209 & -0.0193 & -0.0345 \\
\hline & $(0.0347)$ & $(0.0357)$ & $(0.0454)$ & $(0.0432)$ & $(0.0296)$ & $(0.0313)$ & $(0.0380)$ \\
\hline \multirow[t]{2}{*}{ _cons } & $0.945^{* * *}$ & $0.928 * * *$ & $0.868 * * *$ & $0.905^{* * *}$ & $0.836 * * *$ & $0.828 * * *$ & $0.809 * * *$ \\
\hline & $(0.0886)$ & $(0.0863)$ & $(0.103)$ & $(0.0850)$ & $(0.0835)$ & $(0.0852)$ & $(0.0848)$ \\
\hline $\mathrm{N}$ & 961 & 961 & 690 & 961 & 962 & 962 & 962 \\
\hline R-sq & 0.219 & 0.217 & 0.249 & 0.225 & 0.238 & 0.237 & 0.240 \\
\hline
\end{tabular}


Table 6. Robustness of Main Results to Controls

\begin{tabular}{|c|c|c|c|c|c|c|c|c|c|}
\hline & (1) & (2) & (3) & (4) & (5) & (6) & (7) & (8) & (9) \\
\hline & \multicolumn{9}{|c|}{ Dependent Variable $=$ share of current offenses convicted } \\
\hline any_vänster & 0.00671 & 0.0387 & 0.0414 & 0.0384 & 0.0341 & 0.0362 & 0.0352 & 0.0419 & 0.0299 \\
\hline any_swededem & $-0.155^{*}$ & $-0.171 *$ & $-0.172 *$ & $-0.191 * *$ & $-0.185^{* *}$ & $-0.208 * *$ & $-0.219 * *$ & $-0.224 * *$ & $-0.218 * *$ \\
\hline any_vänster*any_female_vic & $0.120 * *$ & $0.130 * *$ & $0.131 * *$ & $0.144 * *$ & $0.133 * *$ & $0.125 * *$ & $0.127 * *$ & $0.121 * *$ & $0.135 * *$ \\
\hline any_swededem*any_female_vic & 0.0838 & 0.0869 & 0.0894 & 0.114 & 0.115 & 0.144 & 0.147 & 0.153 & 0.154 \\
\hline any_vänster*def_arabic name & -0.0217 & -0.00188 & -0.00520 & -0.0219 & 0.000386 & 0.000956 & 0.000409 & -0.00447 & -0.0227 \\
\hline any_swededem*def_arabic name & $0.170 * *$ & $0.217 * *$ & $0.228 * *$ & $0.259 * * *$ & $0.253 * * *$ & $0.248 * *$ & $0.241 * *$ & $0.250 * *$ & $0.252 * *$ \\
\hline any_vänster*def<21 & -0.0610 & $-0.113 *$ & $-0.126 *$ & $-0.123 *$ & $-0.135^{* *}$ & $-0.122 *$ & $-0.131 * *$ & $-0.147 * *$ & $-0.134 *$ \\
\hline any_swededem*def<21 & $0.281 * * *$ & $0.295 * * *$ & $0.281 * * *$ & $0.278 * * *$ & $0.266 * * *$ & $0.284 * * *$ & $0.296 * * *$ & $0.308 * * *$ & $0.319 * * *$ \\
\hline def_arabic_name & -0.00974 & -0.0274 & -0.0294 & -0.0246 & -0.0131 & -0.0170 & -0.0236 & -0.0186 & -0.0127 \\
\hline any_female_vic & -0.0272 & -0.0284 & -0.0277 & -0.0226 & -0.0363 & -0.0227 & -0.0235 & -0.0203 & -0.0289 \\
\hline def_less 21 & 0.0138 & 0.00223 & 0.00376 & -0.0314 & -0.0319 & -0.0378 & -0.0409 & -0.0319 & -0.0124 \\
\hline Judge Fixed Effects & No & Yes & Yes & Yes & Yes & Yes & Yes & Yes & Yes \\
\hline Other Nämndemän Characteristics & No & No & Yes & Yes & Yes & Yes & Yes & Yes & Yes \\
\hline Defendant Characteristics & No & No & No & Yes & Yes & Yes & Yes & Yes & Yes \\
\hline Case Characteristics & No & No & No & No & Yes & Yes & Yes & Yes & Yes \\
\hline Offense Type Categories & No & No & No & No & No & Yes & Yes & Yes & Yes \\
\hline Criminal History & No & No & No & No & No & No & Yes & Yes & Yes \\
\hline Hearing Year and Day of Week FE & No & No & No & No & No & No & No & Yes & Yes \\
\hline Prosecution Attorney FE & No & No & No & No & No & No & No & No & Yes \\
\hline
\end{tabular}

Each column presents the results of regressing the share of charges resulting in a conviction on the variables listed and the corresponding variables and interaction terms for the green party. No controls are included in column (1); each subsequent column includes the additional set of controls listed in the lower panel of the table. Robust standard errors, clustered on judge name, are used to determine significance, where $* \mathrm{p}<0.10, * * \mathrm{p}<0.05, * * * \mathrm{p}<0.01$. Finally, all specifications condition on the sample who did not fully admit guilt. 


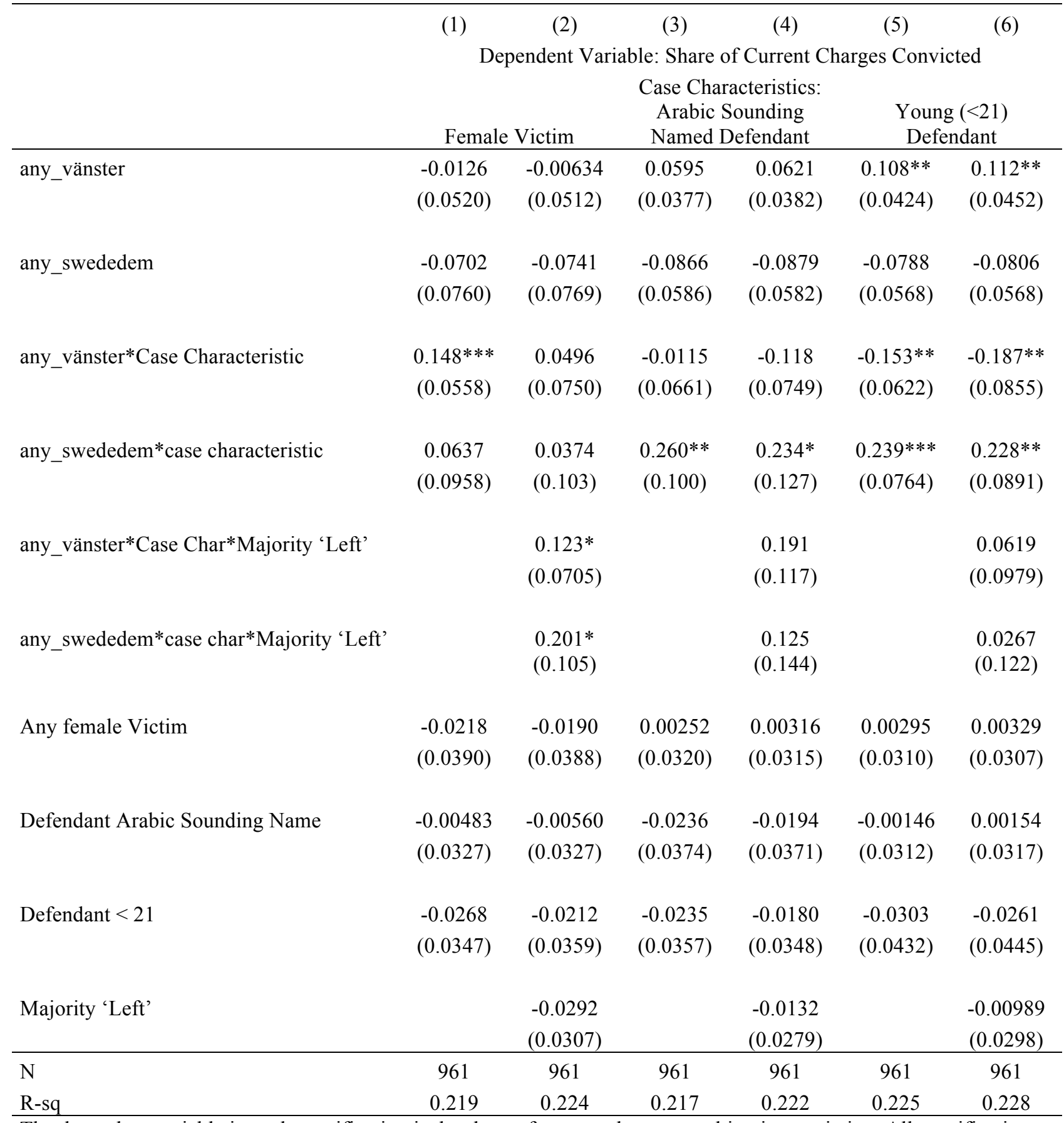

The dependent variable in each specification is the share of current charges resulting in conviction. All specifications include the full set of controls and same restrictions as main specifications (i.e. individuals who do not fully admit guilt). Specifically, controls for judge fixed effects, defendant, offense, case and nämndemän characteristics are characteristics; note that having a green in the triplet, and the corresponding interactions, are also included. 'Left' is defined as vänster, miljö and social democratic parties. The case characteristic included in the interaction varies across columns and is denoted at the top of each column. 
Table 8. Peer Effects

$\begin{array}{cccc}(2) & (3) & (4) & (5) \\ \text { Dependent Variable: Share of Current Offenses Convicted by an Individual Nämndeman }\end{array}$

(5)

Dependent Variable: Share of Current Offenses Convicted

\begin{tabular}{|c|c|c|c|c|c|c|}
\hline & $\begin{array}{c}\text { female victim } \\
\text { cases }\end{array}$ & $\begin{array}{c}\text { no female victim } \\
\text { cases }\end{array}$ & $\begin{array}{c}\text { arabic } \\
\text { defendant } \\
\text { cases }\end{array}$ & $\begin{array}{c}\text { nonarabic } \\
\text { defendant } \\
\text { cases }\end{array}$ & $\begin{array}{c}\text { defendant }<21 \\
\text { cases }\end{array}$ & $\begin{array}{c}\text { defendant }>21 \\
\text { cases }\end{array}$ \\
\hline any_peers_vänster & $\begin{array}{l}0.127 * * * \\
(0.0380)\end{array}$ & $\begin{array}{l}0.00606 \\
(0.0430)\end{array}$ & $\begin{array}{c}0.236 * * * \\
(0.0793)\end{array}$ & $\begin{array}{c}0.0434 \\
(0.0311)\end{array}$ & $\begin{array}{l}-0.0298 \\
(0.0536)\end{array}$ & $\begin{array}{c}0.0989 * * * \\
(0.0333)\end{array}$ \\
\hline any_peers_swededem & $\begin{array}{c}0.0517 \\
(0.0667)\end{array}$ & $\begin{array}{c}-0.107 \\
(0.0771)\end{array}$ & $\begin{array}{l}0.276^{*} \\
(0.162)\end{array}$ & $\begin{array}{l}-0.0363 \\
(0.0501)\end{array}$ & $\begin{array}{c}0.0835 \\
(0.0945)\end{array}$ & $\begin{array}{l}-0.0333 \\
(0.0556)\end{array}$ \\
\hline Judge Fixed Effects & Yes & Yes & Yes & Yes & Yes & Yes \\
\hline Def/Offense/Case Controls & Yes & Yes & Yes & Yes & Yes & Yes \\
\hline Peer Characteristics & Yes & Yes & Yes & Yes & Yes & Yes \\
\hline Own Nämndemän FE & Yes & Yes & Yes & Yes & Yes & Yes \\
\hline $\mathrm{N}$ & 1471 & 1378 & 655 & 2194 & 801 & 2048 \\
\hline R-sq & 0.537 & 0.577 & 0.760 & 0.427 & 0.644 & 0.413 \\
\hline
\end{tabular}

The dependent variable in each each column is the share of current offenses that an idividual nämndeman votes to convict on. Each specification is still restricted to the sample for


nämndeman fixed effects. Robust standard errors, clustered on case, are in parentheses. ${ }^{*} \mathrm{p}<0.10, * * \mathrm{p}<0.05, * * * \mathrm{p}<0.01$. 
Table 9. Which Nämndemän are Most Affected by Their Peers? Heterogeneous Peer Effects

(1) (2) (3) (4) (6) (6)

Dependent Variable: Share of Current Charges Convicted by Individual Nämndeman

\begin{tabular}{|c|c|c|c|c|c|c|c|c|}
\hline & all & females & males & $<50$ & $50-68$ & $>68$ & $<=3$ yrs exp & $>3$ years exp \\
\hline \multicolumn{9}{|c|}{ Panel A: Specifications that include interactions of own peer party and female victim } \\
\hline \multirow[t]{2}{*}{ any_peers_vänster } & 0.0313 & 0.0154 & 0.0658 & 0.0292 & 0.0448 & -0.0112 & -0.00797 & 0.0502 \\
\hline & $(0.0385)$ & $(0.0497)$ & $(0.0508)$ & $(0.0992)$ & $(0.0559)$ & $(0.0615)$ & $(0.0498)$ & $(0.0488)$ \\
\hline \multirow[t]{2}{*}{ Femvictim*any_peers_vänster } & $0.104 * *$ & $0.115^{* *}$ & 0.0867 & 0.179 & 0.104 & 0.126 & $0.169 * * *$ & 0.0731 \\
\hline & $(0.0491)$ & $(0.0579)$ & $(0.0735)$ & $(0.128)$ & $(0.0686)$ & $(0.0858)$ & $(0.0629)$ & $(0.0650)$ \\
\hline \multicolumn{9}{|c|}{ Panel B: Specifications that include interactions of own peer party and defendant arabic sounding } \\
\hline \multirow[t]{2}{*}{ any_peers_swededem } & -0.0394 & 0.00417 & -0.0836 & -0.125 & -0.0710 & 0.0422 & -0.0543 & -0.0219 \\
\hline & $(0.0495)$ & $(0.0555)$ & $(0.0714)$ & $(0.0996)$ & $(0.0675)$ & $(0.0722)$ & $(0.0738)$ & $(0.0593)$ \\
\hline \multirow[t]{2}{*}{ Defarabic*any_peers_swededem } & $0.247 * *$ & $0.235^{*}$ & $0.271 * *$ & 0.156 & $0.331 * *$ & 0.0572 & $0.438 * * *$ & 0.0612 \\
\hline & $(0.109)$ & $(0.128)$ & $(0.133)$ & $(0.162)$ & $(0.140)$ & $(0.207)$ & $(0.136)$ & $(0.141)$ \\
\hline \multicolumn{9}{|c|}{ Panel C: Specifications that include interactions of own peer party and defendant young } \\
\hline \multirow[t]{2}{*}{ any_peers_vänster } & $0.0982 * * *$ & 0.0650 & $0.151 * * *$ & $0.138 * *$ & $0.120 * *$ & 0.0542 & $0.0909 * *$ & $0.105 * *$ \\
\hline & $(0.0312)$ & $(0.0401)$ & $(0.0385)$ & $(0.0633)$ & $(0.0464)$ & $(0.0495)$ & $(0.0392)$ & $(0.0447)$ \\
\hline \multirow[t]{2}{*}{ Youngdef*any_peers_vänster } & -0.0559 & 0.0265 & $-0.136^{* *}$ & -0.121 & -0.0795 & -0.0213 & -0.0427 & -0.0716 \\
\hline & $(0.0507)$ & $(0.0603)$ & $(0.0665)$ & $(0.154)$ & $(0.0667)$ & $(0.0763)$ & $(0.0729)$ & $(0.0694)$ \\
\hline \multirow[t]{2}{*}{ any_peers_swededem } & -0.0364 & 0.0150 & -0.110 & $-0.194^{*}$ & -0.00372 & 0.0238 & -0.00961 & -0.0628 \\
\hline & $(0.0525)$ & $(0.0566)$ & $(0.0752)$ & $(0.102)$ & $(0.0671)$ & $(0.0726)$ & $(0.0773)$ & $(0.0627)$ \\
\hline \multirow[t]{2}{*}{ Youngdef*any_peers_swdem } & $0.218 * * *$ & 0.176 & $0.320 * * *$ & $0.393 * *$ & 0.164 & 0.125 & $0.341 * *$ & $0.223 * *$ \\
\hline & $(0.0744)$ & $(0.111)$ & $(0.103)$ & $(0.153)$ & $(0.126)$ & $(0.130)$ & $(0.148)$ & $(0.0903)$ \\
\hline $\mathrm{N}$ & 2849 & 1470 & 1379 & 684 & 1217 & 948 & 1450 & 1399 \\
\hline
\end{tabular}

Dependent variable $=$ Share of Current Charges on which an individual nämndeman votes to convict . All specifications control for other peer characteristics, defendant, offense, and case characteristics, judge fixed effects, and own nämndemän fixed effects. The full interaction of green, vänster, and swedish democrat

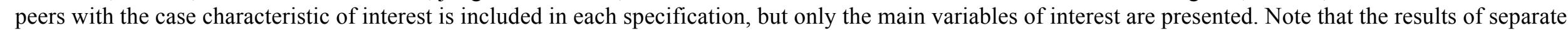
regressions are presented in Panels A, B, and C; each panel considers interactions with a different case characteristics (female victim cases, Arabic named defendant cases, and young defendant cases). Standard errors are in parentheses, and clustered by case. ${ }^{*} \mathrm{p}<0.10, * * \mathrm{p}<0.05, * * * \mathrm{p}<0.01$. 
Table 10. Own Party x Peer Party Interactions

(1)

(2)

(3)

Dependent Variable $=$

Share of current charges on which individual nämndeman votes to convict

Ownvän*peervän

Owngre*peervän

Ownsocdem*peervän

OwnRight*peervän

Ownswedem*peervän

Ownvän*peervän*femvic

Owngre*peervän*femvic

Ownsocdem*peervän*femvic

OwnRight * peervän*femvic

Ownswdem*peervän*femvic

Ownvän*peerswdem

Owngre*peerswdem

Ownsocdem*peerswdem

OwnRight * peerswdem

Ownvän*peerswdem*defarab

Owngre*peerswdem*defarab

Ownsocdem*peerswdem*defarab

OwnRight * peerswdem*defarab

Ownvän*peervän*defyoung

Owngre*peervän*defyoung

Ownsocdem*peervän*defyoung

OwnRight *peervän*defyoung

Ownswdem*peervän*defyoung

Ownvän*peerswdem*defyoung

Owngre*peerswdem*defyoung

Ownsocdem*peerswdem*defyoung

OwnRight *peerswdem*defyoung
$0.182 * *(0.0722)$
$-0.0297 \quad(0.0984)$
$0.0400 \quad(0.0687)$
$-0.0329(0.0506)$
$0.261 * * \quad(0.119)$
$-0.286 * *(0.142)$
$0.165 \quad(0.126)$
$0.125 *(0.0744)$
$0.145 * * \quad(0.0606)$
$-0.0543 \quad(0.168)$

$\begin{array}{rll}--- & 0.0417 & (0.112) \\ --- & 0.0865 & (0.113) \\ --- & 0.0275 & (0.0626) \\ -- & 0.0562 & (0.0346) \\ & & \\ & 0.222 & (0.238) \\ & 0.510^{* *} & (0.212) \\ & 0.164 & (0.126) \\ & -0.0383 & (0.0635)\end{array}$

$0.0743(0.123)$

$0.112(0.129)$

$0.0157 \quad(0.0683)$

$0.0193 \quad(0.0342)$

$\mathrm{N}$ 2835 2835

$0.221 \quad(0.138)$

$0.0541 \quad(0.165)$

$-0.100 \quad(0.0870)$

$-0.113 * *(0.0557)$

$0.174 \quad(0.158)$

$0.125 \quad(0.136)$

$0.289 \quad(0.232)$

$0.178 *(0.104)$

$0.103 * * \quad(0.0514)$

Dependent variable $=$ Share of Current Charges Resulting in Conviction . All specifications control for other peer characteristics, defendant, offense, and case characteristics, judge fixed effects, and own nämndemän fixed effects. Interactions with peer green are also included but not presented. OwnRight indicates that the nämndeman is part of the moderate block (moderate, folk party, center party, or Christian Democrats) or a vägvalet party member (local Gothenburg party that often votes with moderate block). Also note that --- indicates that the listed variable is included in the regression, but that the results are not presented simply to ease readability of the table. Standard errors are in parentheses, and clustered by case. ${ }^{*} \mathrm{p}<0.10, * * \mathrm{p}<0.05, * * * \mathrm{p}<0.01$. 
Table 11. Simulation Exercise: Distinguishing Sway Effects Versus Dissent Aversion in the Case Level Data

\begin{tabular}{|c|c|c|c|c|}
\hline & $\begin{array}{c}(1) \\
\text { Any_curr_Conv } \\
\text { (actual) }\end{array}$ & $\begin{array}{c}(2) \\
\text { Simulated } \\
\text { Conviction } \\
\end{array}$ & $\begin{array}{c}(3) \\
\text { Any_curr_Conv } \\
\text { (actual) }\end{array}$ & $\begin{array}{c}(4) \\
\text { Simulated } \\
\text { Conviction }\end{array}$ \\
\hline \multirow[t]{2}{*}{ any_vänster } & -0.022 & -0.020 & 0.062 & 0.054 \\
\hline & $(0.043)$ & $(0.044)$ & $(0.032)$ & $(0.034)$ \\
\hline \multirow[t]{2}{*}{ any_swededem } & 0.046 & 0.050 & -0.033 & -0.032 \\
\hline & $(0.064)$ & $(0.067)$ & $(0.050)$ & $(0.052)$ \\
\hline \multirow[t]{2}{*}{ any_vänster*any_femalevic } & $0.164 * * *$ & $0.136^{* *}$ & & \\
\hline & $(0.059)$ & $(0.060)$ & & \\
\hline \multirow[t]{2}{*}{ any_swedem*any_femalevic } & -0.056 & -0.067 & & \\
\hline & $(0.088)$ & $(0.092)$ & & \\
\hline \multirow[t]{2}{*}{ any_vänster*def_arabic name } & & & -0.031 & -0.038 \\
\hline & & & $(0.062)$ & $(0.065)$ \\
\hline \multirow[t]{2}{*}{ any_swedem*def_arabic name } & & & $0.263 * * *$ & $0.249 * * *$ \\
\hline & & & $(0.083)$ & $(0.093)$ \\
\hline \multirow[t]{2}{*}{ def_arabic_name } & 0.006 & 0.0066 & 0.0094 & 0.016 \\
\hline & $(0.029)$ & $(0.029)$ & $(0.038)$ & $(0.037)$ \\
\hline \multirow[t]{2}{*}{ any_female_vic } & -0.025 & -0.024 & -0.013 & -0.012 \\
\hline & $(0.037)$ & $(0.037)$ & $(0.029)$ & $(0.028)$ \\
\hline \multirow{2}{*}{$\operatorname{def}<21$} & -0.016 & -0.025 & -0.017 & -0.026 \\
\hline & $(0.036)$ & $(0.036)$ & $(0.036)$ & $(0.036)$ \\
\hline \multirow[t]{2}{*}{ _cons } & $0.801 * * *$ & $0.813^{* * *}$ & $0.795^{* * *}$ & $0.804 * * *$ \\
\hline & $(0.097)$ & $(0.101)$ & $(0.094)$ & $(0.101)$ \\
\hline
\end{tabular}

All specifications use the sample of cases where guilt is not fully admitted and include controls for judge fixed effects, defendant, offense, case and nämndemän characteristics; note that having a green in the triplet, and the corresponding interactions, are also included. The dependent variable in the odd columns is the actual case outcome, i.e. whether there was at least one conviction. The dependent variable in the even columns is the simulated verdict, as described in the text. The coefficients and standard errors presented here are based on 500 bootstrapped samples of size 888 ; this table present the mean and standard deviation of the estimated regression results for these 500 samples. $* \mathrm{p}<0.10, * * \mathrm{p}<0.05, * * * \mathrm{p}<0.01$. 
Table 12. Simulation Exercise: Distinguishing Sway Effects Versus Dissent Aversion in the Peer Effects Analysis

\begin{tabular}{|c|c|c|c|c|c|c|}
\hline & $\begin{array}{c}(1) \\
\text { female } \\
\text { victim }\end{array}$ & $\begin{array}{c}(2) \\
\text { no female } \\
\text { victim }\end{array}$ & $\begin{array}{c}\text { (3) } \\
\text { arabic } \\
\text { defendant }\end{array}$ & $\begin{array}{c}\text { (4) } \\
\text { nonarabic } \\
\text { defendant }\end{array}$ & $\begin{array}{c}(5) \\
\text { Defendant } \\
<21\end{array}$ & $\begin{array}{c}(6) \\
\text { Defendant } \\
>21\end{array}$ \\
\hline \multicolumn{7}{|c|}{ Panel A: Dependent Variable = Actual Any Current Convictions } \\
\hline any_peers_vänster & $\begin{array}{c}0.143^{* * *} * \\
(0.041)\end{array}$ & $\begin{array}{c}-0.001 \\
(0.050)\end{array}$ & $\begin{array}{c}0.233 * * \\
(0.114)\end{array}$ & $\begin{array}{c}0.054 \\
(0.032)\end{array}$ & $\begin{array}{c}-0.010 \\
(0.095)\end{array}$ & $\begin{array}{c}0.094 * * \\
(0.037)\end{array}$ \\
\hline any_peers_swededem & $\begin{array}{c}0.036 \\
(0.081)\end{array}$ & $\begin{array}{l}-0.022 \\
(0.099)\end{array}$ & $\begin{array}{c}0.254 \\
(0.269)\end{array}$ & $\begin{array}{c}0.009 \\
(0.052)\end{array}$ & $\begin{array}{c}0.031 \\
(0.187)\end{array}$ & $\begin{array}{c}0.025 \\
(0.060)\end{array}$ \\
\hline \multicolumn{7}{|c|}{ Panel B: Dependent Variable $=$ Simulated Conviction } \\
\hline any_peers_vänster & $\begin{array}{c}0.105 * * \\
(0.043)\end{array}$ & $\begin{array}{l}-0.013 \\
(0.053)\end{array}$ & $\begin{array}{c}0.146 \\
(0.123)\end{array}$ & $\begin{array}{c}0.027 \\
(0.033)\end{array}$ & $\begin{array}{c}-0.007 \\
(0.094)\end{array}$ & $\begin{array}{l}0.066^{*} \\
(0.038)\end{array}$ \\
\hline any_peers_swededem & $\begin{array}{c}.036 \\
(.083)\end{array}$ & $\begin{array}{l}-0.036 \\
(0.102)\end{array}$ & $\begin{array}{c}0.237 \\
(0.300)\end{array}$ & $\begin{array}{c}0.002 \\
(0.057)\end{array}$ & $\begin{array}{c}0.018 \\
(0.201)\end{array}$ & $\begin{array}{c}0.008 \\
(0.064)\end{array}$ \\
\hline Judge Fixed Effects & Yes & Yes & Yes & Yes & Yes & Yes \\
\hline Def/Offense/Case Controls & Yes & Yes & Yes & Yes & Yes & Yes \\
\hline Peer Characteristics & Yes & Yes & Yes & Yes & Yes & Yes \\
\hline Own Nämndemän FE & Yes & Yes & Yes & Yes & Yes & Yes \\
\hline
\end{tabular}




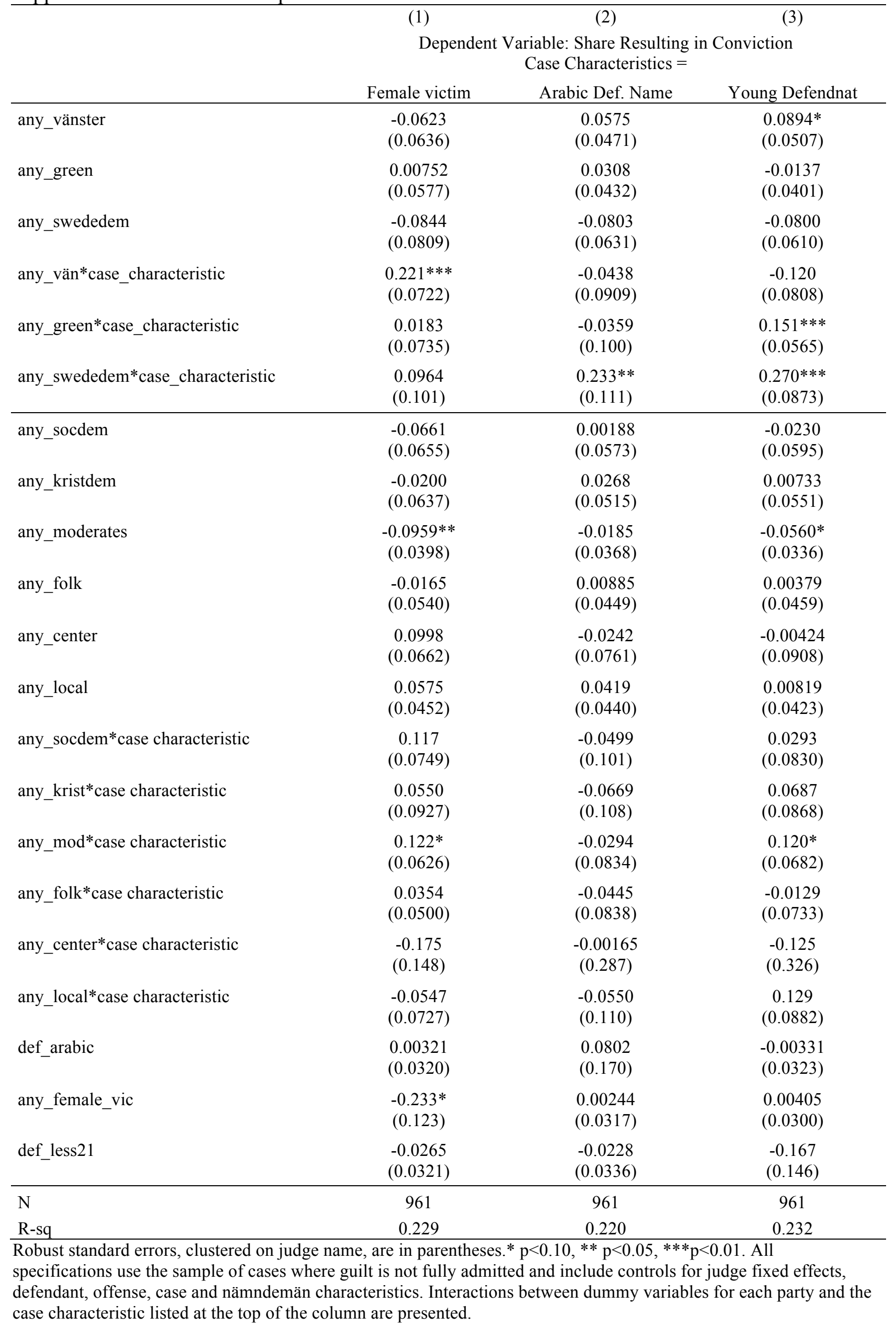


Appendix Table 2. Determinants of Individual Nämndemän Dissenting Opinions

(1)

(2)

Dependent Variable: Dissent from Verdict for at Least One Offense

'Right' (moderate, folk, kristdem, 'Left' (vänster, green, social dems) center) nämndemän nämndemän

\begin{tabular}{|c|c|c|c|c|}
\hline \multicolumn{5}{|c|}{ Own nämndemän Characteristics } \\
\hline own_vänster & & & 0.00455 & $(0.0098)$ \\
\hline own_green & & & -0.000136 & $(0.0101)$ \\
\hline own_sweddem & 0.0125 & $(0.0254)$ & & \\
\hline $\begin{array}{l}\text { own_moderate } \\
\text { own_folk/christian }\end{array}$ & -0.0119 & $(0.0158)$ & & \\
\hline dem/center & 0.00252 & $(0.0167)$ & & \\
\hline own_male & 0.00723 & $(0.0080)$ & 0.00842 & $(0.0091)$ \\
\hline own_age & -0.000565 & $(0.0004)$ & -0.000039 & $(0.0003)$ \\
\hline own_nonswedish & 0.00718 & $(0.0195)$ & 0.000145 & $(0.0083)$ \\
\hline own_exp & 0.0000277 & $(0.0008)$ & -0.00133 & $(0.0010)$ \\
\hline \multicolumn{5}{|l|}{ Peer Characteristics } \\
\hline any_peers_green & -0.00698 & $(0.0090)$ & 0.00846 & $(0.0127)$ \\
\hline any_peers_vänster & 0.0117 & $\left(\begin{array}{ll}0 & .0122\end{array}\right)$ & $-0.0116 * * *$ & $(0.0039)$ \\
\hline any_peers_sweddem & $-0.0178 * * *$ & $(0.0057)$ & 0.0193 & $(0.0182)$ \\
\hline num_male_peers & -0.00137 & $(0.0078)$ & $0.0116 * *$ & $(0.0056)$ \\
\hline any_nonsw_peers & 0.00461 & $(0.0083)$ & -0.00285 & $(0.0070)$ \\
\hline total_peer_experience & $-0.00121 *$ & $(0.0007)$ & -0.000342 & $(0.0005)$ \\
\hline peer_avgage & 0.000159 & $(0.0004)$ & -0.000185 & $(0.0004)$ \\
\hline \multicolumn{5}{|c|}{ Defendant and Case Characteristics } \\
\hline def_male & $0.0138 * * *$ & $(0.0051)$ & -0.00770 & $(0.0122)$ \\
\hline def_less 21 & $-0.0132 *$ & $(0.0079)$ & -0.00651 & $(0.0071)$ \\
\hline def_nonswedish & $0.0303 *$ & $(0.0170)$ & -0.00338 & $(0.0089)$ \\
\hline def_arabic & 0.00786 & $(0.0106)$ & 0.0129 & $(0.0103)$ \\
\hline num_victims & 0.00269 & $(0.0033)$ & -0.000197 & $(0.0024)$ \\
\hline any_female_vic & -0.00885 & $(0.0095)$ & -0.00316 & $(0.0058)$ \\
\hline num_defendants & -0.000994 & $(0.0016)$ & 0.00266 & $(0.0026)$ \\
\hline partial_admission & 0.00261 & $(0.0087)$ & -0.00204 & $(0.0065)$ \\
\hline num_offenses & 0.00524 & $(0.0056)$ & -0.000657 & $(0.0026)$ \\
\hline any_robbery & -0.0167 & $(0.0119)$ & $-0.0186^{*}$ & $(0.0105)$ \\
\hline any_rape & $0.0631 * * *$ & $(0.0232)$ & 0.0268 & $(0.0179)$ \\
\hline any_assault & -0.00869 & $(0.0104)$ & 0.00478 & $(0.0079)$ \\
\hline any_aggassault & 0.00559 & $(0.0137)$ & 0.00848 & $(0.0114)$ \\
\hline any_unlaw_threat & -0.00420 & $(0.0103)$ & -0.00414 & $(0.0071)$ \\
\hline any_hom & $-0.0188^{*}$ & $(0.0109)$ & -0.00440 & $(0.0086)$ \\
\hline any_drunkdrive & -0.0243 & $(0.0159)$ & 0.00374 & $(0.0076)$ \\
\hline any_drugs & -0.0206 & $(0.0146)$ & $-0.00784^{*}$ & $(0.0044)$ \\
\hline any_other_sex & -0.0133 & $(0.0163)$ & 0.00836 & $(0.0133)$ \\
\hline any_other & 0.00168 & $(0.0098)$ & -0.00303 & $(0.0086)$ \\
\hline cons & 0.0357 & $(0.0323)$ & 0.0205 & $(0.0313)$ \\
\hline $\bar{N}$ & 1414 & & 1350 & \\
\hline $\mathrm{R}$-sq & 0.053 & & 0.023 & \\
\hline
\end{tabular}

Robust standard errors, clustered on case number, are in parentheses.* $\mathrm{p}<0.10,{ }^{* *} \mathrm{p}<0.05$, *** $<<0.01$. 
Appendix Table 3. Own Party Effects on Conviction by Case Characteristics

\begin{tabular}{|c|c|c|c|c|c|c|}
\hline & $(1)$ & $(2)$ & (3) & (4) & $(5)$ & (6) \\
\hline & \multicolumn{6}{|c|}{ Dependent Variable: Share of Current Charges On Which Individual Nämndeman Votes to Convict } \\
\hline & $\begin{array}{c}\text { female victim } \\
\text { cases }\end{array}$ & $\begin{array}{c}\text { no female victim } \\
\text { cases }\end{array}$ & $\begin{array}{c}\text { arabic defendant } \\
\text { cases }\end{array}$ & $\begin{array}{c}\text { nonarabic } \\
\text { defendant cases }\end{array}$ & $\begin{array}{c}\text { defendant }<21 \\
\text { cases }\end{array}$ & $\begin{array}{c}\text { defendant }>21 \\
\text { cases }\end{array}$ \\
\hline \multirow[t]{2}{*}{ own_vänster } & $0.0967 * *$ & 0.0274 & 0.0805 & 0.0452 & 0.0475 & $0.0618 *$ \\
\hline & $(0.0409)$ & $(0.0518)$ & $(0.0784)$ & $(0.0385)$ & $(0.0742)$ & $(0.0365)$ \\
\hline \multirow[t]{2}{*}{ own_green } & 0.0271 & 0.0210 & -0.132 & 0.00161 & $0.191 * *$ & -0.0245 \\
\hline & $(0.0413)$ & $(0.0508)$ & $(0.0807)$ & $(0.0368)$ & $(0.0860)$ & $(0.0369)$ \\
\hline \multirow[t]{2}{*}{ own_swededem } & 0.00766 & -0.140 & 0.0948 & -0.0831 & 0.183 & -0.0958 \\
\hline & $(0.0746)$ & $(0.0937)$ & $(0.168)$ & $(0.0583)$ & $(0.140)$ & $(0.0641)$ \\
\hline \multirow[t]{2}{*}{ own_moderate } & -0.0162 & -0.0270 & -0.0990 & -0.0211 & $0.164 * *$ & -0.0203 \\
\hline & $(0.0300)$ & $(0.0395)$ & $(0.0719)$ & $(0.0251)$ & $(0.0822)$ & $(0.0257)$ \\
\hline \multirow[t]{2}{*}{$\begin{array}{l}\text { own_fkrc (folk, christ, } \\
\text { center) }\end{array}$} & -0.00809 & 0.0340 & $-0.199 * *$ & $0.0528 *$ & $0.169 * *$ & 0.0225 \\
\hline & $(0.0341)$ & $(0.0465)$ & $(0.0778)$ & $(0.0301)$ & $(0.0764)$ & $(0.0288)$ \\
\hline Judge Fixed Effects & Yes & Yes & Yes & Yes & Yes & Yes \\
\hline Def/Offense/Case Controls & Yes & Yes & Yes & Yes & Yes & Yes \\
\hline Peer Nämndemän FE & Yes & Yes & Yes & Yes & Yes & Yes \\
\hline $\mathrm{N}$ & 1469 & 1373 & 657 & 2185 & 795 & 2047 \\
\hline R-sq & 0.665 & 0.677 & 0.855 & 0.535 & 0.721 & 0.532 \\
\hline
\end{tabular}

Dependent Variable = Share of Current Charges that Individual Nämndemän votes to convict on. The sample includes those individuals who did not

fully admit guilt. Each column further restricts the sample to a sub-sample indicated at the top of the column. All specifications control for judge fixed effects, defendant, offense, and case charactersitics, as well as fixed effects for each nämndeman peer. In addition, own characteristics (other than party) are also included as controls. Robust standard errors, clustered on case, are in parentheses. ${ }^{*} \mathrm{p}<0.10, * * \mathrm{p}<0.05, * * * \mathrm{p}<0.01$. 